\title{
If People Would Be Outraged by Their Rulings, Should Judges Care?
}

\section{Citation}

Cass R. Sunstein, If People Would Be Outraged by Their Rulings, Should Judges Care? (John M. Olin Program in Law \& Economics Working Paper No. 332, 2007).

\section{Published Version}

http://chicagounbound.uchicago.edu/law_and_economics/248/

\section{Permanent link}

http://nrs.harvard.edu/urn-3:HUL.InstRepos:13015046

\section{Terms of Use}

This article was downloaded from Harvard University's DASH repository, and is made available under the terms and conditions applicable to Other Posted Material, as set forth at http:// nrs.harvard.edu/urn-3:HUL.InstRepos:dash.current.terms-of-use\#LAA

\section{Share Your Story}

The Harvard community has made this article openly available.

Please share how this access benefits you. Submit a story.

\section{Accessibility}




\section{University of Chicago Law School Chicago Unbound}

Coase-Sandor Working Paper Series in Law and

Economics

Coase-Sandor Institute for Law and Economics

2007

\section{If People Would Be Outraged by Their Rulings, Should Judges Care?}

Cass R. Sunstein

Follow this and additional works at: http://chicagounbound.uchicago.edu/law_and_economics Part of the Law Commons

\section{Recommended Citation}

Cass R. Sunstein, "If People Would Be Outraged by Their Rulings, Should Judges Care?" (John M. Olin Program in Law and Economics Working Paper No. 332, 2007).

This Working Paper is brought to you for free and open access by the Coase-Sandor Institute for Law and Economics at Chicago Unbound. It has been accepted for inclusion in Coase-Sandor Working Paper Series in Law and Economics by an authorized administrator of Chicago Unbound. For more information, please contact unbound@law.uchicago.edu. 


\title{
CHICAGO
}

JoHn M. Olin LAW \& ECONOMICS WORKING PAPER NO. 332

(2D SERIES)

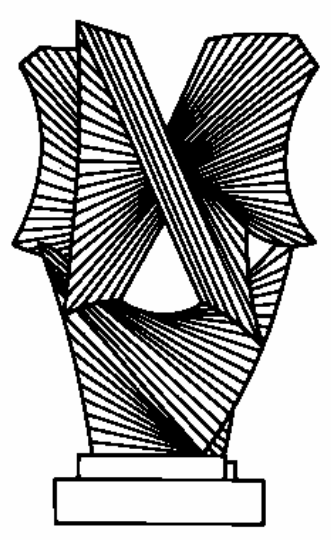

\section{If People Would Be Outraged by Their Rulings, Should Judges Care?}

\author{
Cass R. Sunstein
}

\section{THE LAW SCHOOL THE UNIVERSITY OF CHICAGO}

February 2007

This paper can be downloaded without charge at the John M. Olin Program in Law and Economics Working Paper Series: http://www.law.uchicago.edu/Lawecon/index.html and the Social Science Research Network Electronic Paper Collection:

http://ssrn.com/abstract_id $=965581$ 


\title{
If People Would Be Outraged by Their Rulings, Should Judges Care?
}

\author{
Cass R. Sunstein ${ }^{*}$
}

\begin{abstract}
At first glance, it is puzzling to suggest that courts should care whether the public would be outraged by their decisions; judicial anticipation of public outrage and its effects seems incompatible with judicial independence. Nonetheless, judges might be affected by the prospect of outrage for both consequentialist and epistemic reasons. If a judicial ruling would undermine the cause it is meant to promote or impose serious social harms, judges have reason to hesitate on consequentialist grounds. The prospect of public outrage might also suggest that the Court's ruling would be incorrect on the merits; if most people disagree with the Court's decision, perhaps the Court is wrong. Those who adopt a method on consequentialist grounds are more likely to want to consider outrage than are those who adopt an interpretive method on nonconsequentialist grounds (including some originalists). The epistemic argument for attention to outrage is greatly weakened if people suffer from a systematic bias or if the public view is a product of an informational, moral, or legal cascade. There is also a strong argument for banning consideration of the effects of public outrage on ruleconsequentialist grounds. Judges might be poorly suited to make the relevant inquiries, and consideration of outrage might produce undue timidity. These points have general implications for those who favor "popular constitutionalism," or judicial restraint, on democratic grounds. An understanding of the consequentialist and epistemic grounds for judicial attention to public outrage also offers lessons for the decisions of other public officials, including presidents, governors, and mayors, who might be inclined to make decisions that will produce public outrage.
\end{abstract}

\section{Introduction}

Judicial rulings can, and sometimes do, provoke public outrage. If the Supreme Court ruled that states must recognize same-sex marriages, national politics would undoubtedly be affected, and a movement for a constitutional amendment would be all but inevitable. If the Court said that the Establishment Clause forbids the use of the words "under God" in the Pledge of Allegiance, ${ }^{1}$ the Court would face a great deal of public outrage. If the Court struck down measures designed to protect against the risk of

\footnotetext{
* Karl N. Llewellyn Distinguished Service Professor, Law School and Department of Political Science, University of Chicago. I am grateful to Bernard Harcourt, Daryl Levinson, Anup Malani, Gerald Newman, Jeremiah Purdy, Adam Samaha, and Adrian Vermeule for valuable comments in a previous draft. Participants in workshops at Harvard Law School and the University of Chicago Law School provided exceptionally valuable help. Matthew Robson provided superb research assistance.

${ }^{1}$ The Court avoided this issue in Elk Grove Unified Sch. Dist. v. Newdow, 542 U.S. 1 (2004).
} 
terrorism, especially in a period in which the risk was acutely felt, significant parts of the public would be outraged as well. Many judges are drawn, on occasion, to interpretations of the Constitution that would outrage large segments of the public. How, if at all, should courts think about, or deal with, the prospect of outrage?

A detailed literature attempts to show that the Supreme Court's decisions are generally in line with public opinion and that, in light of the Court's actual practices, the "countermajoritarian difficulty”, is far less difficult than it might seem. ${ }^{3}$ To this extent, a degree of "popular constitutionalism,"4 captured in a measure of public control of constitutional meaning, seems to be alive and well. The Court rarely embarks on courses of action that are wildly out of step with the strongly held views of citizens as a whole. ${ }^{5}$ But there can be no question that the Court's decisions can provoke public outrage, and that the Court sometimes works to reduce the likelihood and intensity of that outrage. ${ }^{6}$ The most famous example is Naim v. Naim, ${ }^{7}$ in which the Court refused to rule on the constitutionality of a ban on racial intermarriage, largely because it feared that its ruling would provoke outrage, in a way that might diminish the Court's own authority. ${ }^{8}$ It is reasonable to speculate that the Court's refusal to decide the constitutionality of the use of the words "under God," in the Pledge of Allegiance, had similar motivations. ${ }^{9}$ The use of the "passive virtues," including justiciability doctrines, is often understood as an effort to ensure that the Court's timing is "prudent," in the sense of ensuring that judicial decisions do not produce public reactions that will compromise the Court's goals. ${ }^{10}$

My topic here is the normative question, not the positive one. With respect to anticipated public outrage, the positive issues have received sustained attention, whereas

\footnotetext{
2 See Alexander BiCKel, The LeAst Dangerous Branch, 16-23 (1965).

${ }^{3}$ For an early treatment, see Robert Dahl, Decisionmaking in a Democracy: The Supreme Court as National Policymaker, 6 J. PUB. LAW 279 (1957). For a recent and broadly compatible discussion, see Michael Klarman, From Jim Crow to Civil Rights (2004).

${ }^{4}$ See LARry Kramer, The PeOPle Themselves (2004).

${ }^{5}$ See Dahl, supra note 3.

${ }^{6}$ Compare Bickel, supra note 2, at 111-198 (supporting the use of justiciability doctrines to assist the Court in exercising the "passive virtues"), with Gerald Gunther, The Subtle Vices of the Passive Virtues, 64 COLUM. L. REV. 1 (1964) (criticizing use of justiciability doctrines to avoid principled decisionmaking).

${ }^{7} 350$ U.S. 891 (1955).

${ }^{8}$ See BICKEL, supra note 2, at 174.

${ }^{9}$ See Elk Grove Unified Sch. Dist. v. Newdow, 542 U.S. 1 (2004);

${ }^{10}$ See BICKEL, supra note 2.
} 
the normative issues have been explored only episodically. ${ }^{11}$ My principal goal is to investigate whether and why anticipated public outrage should matter to judicial decisions. $^{12}$ At first glance, an affirmative answer seems quite jarring; many people believe that courts should interpret the Constitution without attention to the possible objections of the public. ${ }^{13}$ On this view, the central point of constitutional law, or at least judicial review, is to impose an obstacle to public judgments and sometimes to override those judgments even if they are intensely held. It would be odd to say that the Supreme Court should not protect free speech or should allow racial discrimination if and because it anticipates that the public would be outraged by protection of free speech or by bans on racial discrimination. The idea that the Court should anticipate and consider the effects of public outrage seems inconsistent with the role of an independent judiciary in the constitutional system.

Questioning the standard view, I shall suggest two reasons why public outrage might matter. The first is consequentialist; the second is epistemic. The consequentialist reason is that if a ruling would turn out to have terrible consequences, judges should take that possibility into account. This claim depends on the assumption that the argument for judicial rulings depends, in part, on their effects. It is all very well to say that judges should rule as they see fit even if the heavens would fall. But if the heavens really would fall, judges should not rule as they see fit. The epistemic reason involves humility: Judges cannot always know whether they are right, even about the meaning of the Constitution, and intense public convictions may provide relevant information about the correctness of their conclusions. Whether public convictions are pertinent depends in part on their foundations and in part on the prevailing method of constitutional interpretation. If the

\footnotetext{
${ }^{11}$ The most sustained treatment is id., with the emphasis on the "passive virtues" as a response, in part, to the problem of public outrage. As we shall see, however, Bickel did not provide firm underpinnings for the Court's consideration of public disapproval of its decisions, and was hence left vulnerable to the charge of opportunism. See Gunther, supra note 6 (criticizing use of passive virtues as unprincipled).

${ }^{12}$ There is an obvious relationship between this topic and the general one of "popular constitutionalism," which sees We the People as a kind of tribunal of last resort. See KrAMER, supra note 4. I offer a few remarks on the relationship below.

${ }^{13}$ This view can be found, in one or another form, in Ronald Dworkin, Justice IN RoBes (2006); Geoffrey Stone, Perilous Times (2005); and Antonin Scalia, The Rule of Law is A Law of Rules, 56 U. CHI. L. REV. 1175, 1180 (1989). We might take this view as standard while acknowledging that many people believe that doctrines of justiciability are properly used to limit the Court's intervention in deference to public reaction. See BICKEL, supra note 2 . To the extent that this belief is widely held, as it may be, the argument here might be seen as an effort to explain how it might be best defended.
} 
prevailing method makes constitutional adjudication turn on disputable judgments of fact or morality, the beliefs of the public may indeed be relevant. It is important, however, to know whether these public beliefs are subject to a systematic bias or to cascade effects. If so, there is much less reason to consider them, because they lack epistemic credentials.

To assess the consequentialist and epistemic grounds for considering public outrage, it is necessary to distinguish between invalidations and validations of decisions of the elected branches. Courts have far more reason to consider outrage before invalidating such decisions than before validating them; statutory interpretation generally belongs in the same category as validations. There is, however, a plausible ruleconsequentialist argument for asking judges not to consider public outrage even in the context of invalidations: Judicial judgments about outrage may be unreliable, and consideration of outrage may produce excessive judicial timidity. While plausible in the abstract, this argument depends on contestable empirical assumptions and may turn out to be wrong. If it is clear that a decision would outrage the public and that such outrage would be both intense and very harmful, courts have reason to hesitate before invalidating the decisions of the elected branches. My principal goal is not, however, to defend judicial attention to outrage, but to explore the grounds on which both consideration of outrage and indifference to outrage might be defended.

A recurring issue is whether judges have enough information to be confident about either their judgments on the merits or their assessments of the existence and effects of outrage. It is helpful to begin by assuming that they have such information and by seeing how the analysis proceeds on that (admittedly unrealistic) assumption. Once the assumption is relaxed, the consequentialist argument for considering outrage is weakened, while the epistemic argument is strengthened. Those who believe that courts should refuse to attend to public outrage are on secure grounds if judges have little information about the likely effects of their rulings and a great deal of information about the proper interpretation of the Constitution. Those who believe that public outrage is highly relevant are likely to assume that in assessing consequences, judges are not at 
sea-and more fundamentally that judges do not have special or unique access to constitutional meaning. ${ }^{14}$

While my focus is on public outrage and its consequences, the discussion will bear on some larger questions. Nearly every public institution is barred from taking account of certain considerations that plainly ought to matter from a consequentialist perspective. The ban on consideration of certain factors often operates as a legal or moral taboo; but why? The most plausible answer is that in some settings, the overall consequences are much better if institutions refuse to take account of certain consequences. A more implication is that in both the private and public spheres, "role morality” - the particular moral principles associated with particular social roles - may be best justified on rule-consequentialist grounds.

If the analysis of the consequentialist and epistemic arguments has force, it should also have general implications for those who favor "popular constitutionalism" 15 and for those who are skeptical about the institution of judicial review on democratic grounds. ${ }^{16}$ Some of the best arguments for popular constitutionalism, and for those who challenge judicial rule, may well be epistemic in character; perhaps the citizenry has a better understanding, under some circumstances, of how the founding document should be construed. ${ }^{17}$ But I shall raise serious questions about both consequentialist and epistemic arguments for considering outrage, and by understanding the limitations of those arguments, we shall be in a better position to assess the claims of those who question judicial review in the name of democracy. A general lesson is that no conclusions - about the proper response to outrage, popular constitutionalism, or judicial review-can be established in the abstract, or though large-scale claims about the goals and nature of selfgovernment.

As we shall see, the epistemic argument for considering outrage is based on the general idea that large groups of people are highly likely to be right, at least if most group members are at least somewhat likely to be right. This idea helps to explain recent

\footnotetext{
${ }^{14}$ This is the central argument in James Bradley Thayer, The Origin and Scope of the American Doctrine of Constitutional Law, 7 HARV. L. REV. 129 (1893).

15 See KRAMER, supra note 4; JEREMY WALDRON, LAW AND DISAGREEMENT (2004).

16 See, e.g., AdRIAN VERMEULE, JUdGing UndER UNCERTAINTY (2006).

17 See MARK TUSHNET, TAKING THE CONSTITUTION AWAY FROM THE COURTS (1998).
} 
enthusiasm for the "wisdom of crowds." ${ }^{, 18}$ With respect to constitutional interpretation, however, crowds may not be so wise, because they may suffer from a systematic bias, or because their judgments may be a product of informational cascades, often induced by "meaning entrepreneurs." An understanding of the problems introduced by systematic biases, and by cascade effects, bears both on popular constitutional and the risk that large groups may be quite mistaken.

This Article comes in six parts. Part II discusses invalidations and consequentialist arguments for considering public outrage. Part III explores the possibility that when outrage is anticipated, judges should take it into account for epistemic reasons. Part IV turns to the case of validations, with brief reference to the question of statutory interpretation. Part $\mathrm{V}$ discusses approaches to constitutional interpretation that might seem to counsel against considering outrage; originalism is the main example here, but those who emphasize "moral readings" of the Constitution might also be skeptical of the idea that judges should consider outrage. Part V also considers minority outrage. Part VI briefly explores the relevance of the consequentialist and epistemic arguments for others exercising public authority, including presidents, legislators, governors, mayors, and jurors. A primary claim here is that when officials consider public outrage, they might be humble rather than cowardly, acting as they do because they believe their own judgments are imperfectly reliable.

\section{Invalidations and Consequences}

Let us begin with cases posing the question whether anticipated public outrage should play a role in a judge's decision whether to vote to invalidate a decision of the elected branches, whether state or federal, on constitutional grounds. As we shall see, such cases present the strongest arguments for considering outrage. Throughout I shall assume that a strong majority of the public, rather than a minority, is outraged; I shall turn to the case of minority outrage in due course. ${ }^{19}$

\footnotetext{
${ }^{18}$ See JAmes Surowiecki, The Wisdom of Crowds (2004); SCOtT PAge, The DifFerence (2007).

${ }^{19}$ See infra.
} 


\section{A. The Problem}

Suppose that a member of the Supreme Court, Justice Bentham, is convinced after due deliberation of the following propositions:

1A. The ban on same-sex marriages is a violation of the Equal Protection Clause.

1B. The ban on polygamous marriages is a violation of the Due Process Clause.

1C. The use of the words "under God," in the Pledge of Allegiance, is a violation of the Establishment Clause.

1D. Capital punishment is inconsistent with the Eighth Amendment.

1E. The President may not commit troops to a military conflict without either a formal declaration of war or an authorization to use force from Congress.

1F. Racial segregation in a high-security prison is a violation of the Equal Protection Clause.

Suppose that all six of these propositions are at issue in cases before the Court (it is an exciting term). In all six cases, the Court is deadlocked 4-4; Justice Bentham has the deciding vote. Suppose finally that Bentham believes that if he votes as his convictions suggest, there will be extremely serious public opposition, going well beyond disagreement to outrage. In all six cases, he believes that the Court's decision will become highly relevant to national politics, and that those who side with the Court, and even those who do not vigorously oppose it, will suffer badly. In cases 1A-1D, he believes that many officials will refuse to accept the Court's decision, and the Constitution will be amended to overturn the Court's decision. In case $1 \mathrm{E}$, troops have already been committed, and Bentham thinks that from the standpoint of national security, and protection of lives of American soldiers, the Court's decision is very bad. In case $1 \mathrm{~F}$, Bentham believes that if he votes in accordance with his commitments, so as to require immediate desegregation, officials will refuse to obey, and segregation will continue. How should Bentham vote?

To orient the discussion, let us begin with two simplifying assumptions (eventually to be relaxed). First, Bentham has no doubt at all about the correctness of his views in the six cases. He is certain, and he is certain that he has excellent reason to be 
certain, that he is right about the meaning of the Constitution. Second, Bentham has no doubt about his predictions about the consequences of the Court's decision. He happens to have an entirely accurate crystal ball, and he knows what will happen if the Court does as he thinks best, as a matter of principle. Bentham is aware that different consequences might play a different role in his assessment about what to do. Perhaps a constitutional amendment, overturning the Court's decision, is acceptable, whereas a significant increase in the risk to national security is much less so. I will return to these complexities shortly; let us simply stipulate that Bentham has good reason to think that if he votes as he sees fit, very bad consequences will follow.

\section{B. Options, Passivity, Minimalism}

Suppose that Bentham is inclined to consider public outrage in cases $1 \mathrm{~A}-1 \mathrm{~F}$. If the risk is sufficiently serious, it might tip the balance in terms of his ultimate vote. He is likely to ask: What are my options here? Perhaps Bentham can refuse to address the merits at all, postponing them for another day. In case 1C, for example, Bentham might look for some ground, such as standing or ripeness, that would allow him not to express a view on the underlying issues.

To see why, consider Alexander Bickel's influential discussion of the "passive virtues."20 Bickel insisted that the Court's role was not to uncover the Constitution's original meaning but to identify and to announce certain enduring values - to discern principles that would properly organize constitutional life. Bickel believed that courts were in a unique position to carry out that role. In his view, "courts have certain capacities for dealing with matters of principle that legislatures and executives do not possess." ${ }^{21}$ Bickel did not believe that judgments about those matters would be static; he fully recognized the Court's creative role. At the same time, Bickel thought that a heterogeneous society could not possibly be governed by an array of judiciallyannounced principles. In his view, "[n]o good society can be unprincipled; and no viable society can be principle-ridden.”22 On some occasions, the Court should give the political

\footnotetext{
${ }^{20}$ See BICKEL, supra note 2, at 111-98. But see Gunther, supra note 6 (criticizing use of justiciability doctrines to avoid principled decisionmaking).

${ }^{21}$ See BICKEL, supra note 2, at 25.

${ }^{22}$ Id. at 64.
} 
processes relatively free play, by neither upholding nor invalidating its decisions. The Court's task in judicial review is to maintain both "guiding principle and expedient compromise" 23 _ and to do so by staying its hand in the face of strong popular opposition, however indefensible the opposition might be. Bickel did not specify the precise grounds on which courts should stay their hands, but a judgment about the consequences of not doing so would undoubtedly motivate their hesitation.

Perhaps Bentham is unable to exercise the passive virtues so as to avoid addressing the merits. Even if so, Bentham might be able to address the merits in a way that reduces the magnitude and effects of public outrage. He might ensure that the Court rules modestly or in a way that avoids theoretical ambition to the extent possible. Bentham might aim for a degree of narrowness, in the form of a decision that leaves many issues unresolved, or instead shallowness, in the form of a decision that is agnostic on some of the deepest questions. ${ }^{24}$ In case $1 \mathrm{~A}$, for example, Bentham might say: "States must provide the incidents of marriage to same-sex couples; we need not decide whether (or we do not decide that) states must make marriage itself available.” In case 1B, Bentham might say: "States may not forbid religious institutions from performing and respecting polygamous marriages; we need not decide whether (or we do not decide that) states must perform and respect such marriages.” In this way, a minimalist strategy, reducing or eliminating public outrage, might be tempting.

Bentham is most unlikely to want to join the view of those justices with whom he disagrees on the merits; he will not be inclined to commit himself to an interpretation of the Constitution that he rejects on principle. Nor will Bentham want to misstate the actual grounds for his conclusion. ${ }^{25}$ But suppose that he cannot invoke any basis for avoiding

\footnotetext{
${ }^{23} I d$.

${ }^{24}$ See Cass R. Sunstein, One Case At A Time (1999).

${ }^{25}$ This point itself raises serious puzzles. If Bentham is a consequentialist, why will he refuse to lie about the grounds for his judgment, if lying would produce good consequences? One answer is that lies can ultimately produce bad consequences; the publicity condition, requiring officials to act in ways that can be defended honestly and in public, might be understood in these terms. See David Luban, The Publicity Principle, in THE THEORY OF InstituTIONAL DESIGN 154 (1996). Another answer is that notwithstanding his name, Bentham may believe that lying is an intrinsic wrong, because it does not treat his fellow citizens with respect. See David A. Strauss, Persuasion, Autonomy, and Freedom of Expression, 91 Colum. L. REV. 334, 353-61 (1991). Note that Bentham is a consequentialist, not a utilitarian; he may therefore believe that treating people disrespectfully is an independent wrong, one that counts in the consequentialist calculus. See Amartya Sen, Fertility and Coercion, 63 U. CHI. L. Rev. 1035, 1038-39 (1996) (noting possibility of considering rights violations as part of assessment of consequences).
} 
the constitutional question, and that he is certain that if public outrage and its effects are considered, the Court should greatly hesitate before ruling in favor of propositions 1A1F. Perhaps he could write a concurring opinion that starts with these two sentences: "I am not convinced that the prevailing view is correct in its interpretation of the Constitution. But in view of the appropriately modest role of the judiciary in a democratic society, I concur in the judgment.” To make this opinion plausible, Bentham would have to spell out, with some particularity, exactly what is entailed by the second sentence. He might gesture in terms of epistemic considerations, pointing to the need to pay respectful attention to the considered judgments of other branches ${ }^{26}$ and his fellow citizens. He might add a reference to consequentialist considerations, pointing to sharp social divisions and the potentially unfortunate effects of judicial intervention into a sensitive area. $^{27}$ To see how an opinion of this kind might be made plausible, we need to investigate some details.

\section{Kantian Adjudication}

Perhaps Bentham will not attend to intensely held public opposition at all. Perhaps Bentham (notwithstanding his name) is committed to a principle of Kantian adjudication: Even if the heavens will fall, the Constitution must be interpreted properly. Indeed, Kantian adjudication appears to be the informal working theory of judges and lawyers, so much so as to make it plausibly outrageous for judges to defer to outragethough actual judicial practices suggest a far more complicated picture. ${ }^{28}$

According to those who endorse Kantian adjudication, the proper interpretation of the Constitution has nothing to do with what the public believes or wants. The role of the Court is to say what the law is, and its conclusions on that point should have nothing to

\footnotetext{
${ }^{26}$ See Rostker v. Goldberg, 453 U.S. 57, 64 (1981) (noting need to attend to constitutional judgments of other branches).

${ }^{27}$ See Van Orden v. Perry, 545 U.S. 677, 704 (2005) (Breyer, J., concurring) (fearing that deeming a ten commandments display a violation of the Establishment Clause would "encourage disputes concerning the removal of longstanding depictions of the Ten Commandments" and "create the very kind of . . . divisiveness that the Establishment Clause seeks to avoid”); Elk Grove Unified Sch. Dist. v. Newdow, 542 U.S. 1, 15 (2004) (referring to "a highly public debate over . . . the propriety of a widespread national ritual and the meaning of our constitution").

${ }^{28}$ See supra notes $2-11$.
} 
do with the public's will. ${ }^{29}$ Indeed, a sharp separation between law and politics might be thought to depend, crucially, on a commitment to Kantian adjudication. Compare the domain of statutory interpretation. Suppose that Bentham believes that the Endangered Species $\mathrm{Act}^{30}$ compels the termination of a popular and nearly-completed project, ${ }^{31}$ or that the Civil Rights Act of $1964^{32}$ permits affirmative action; ${ }^{33}$ suppose too that both of these rulings will provoke public outrage. At least at first glance, it would seem implausible to say that Bentham should alter his votes about statutory meaning to avoid such outrage. (We will return to the question why this is so. ${ }^{34}$ ) In the context of potential invalidations, the argument for Kantian adjudication might seem even more forceful. Why should judges uphold unconstitutional measures-for example, racial discrimination or restrictions on free speech-merely because the public would be outraged if they refused to do so? Deference to public outrage seems hopelessly inconsistent with the role of judges in a constitutional system.

But for two reasons, there is a serious question whether judges should be unconditionally committed to Kantian adjudication. The first reason is that even Kantians typically believe that moral rules can be subject to consequentialist override if the consequences are sufficiently serious. ${ }^{35}$ If total catastrophe really would ensue, judges should not rule as they believe principle requires. Suppose that the consequence of a ruling consistent with $1 \mathrm{E}$ would be to endanger national security; perhaps judges should refuse to issue that ruling. Consider in this regard Justice Jackson's conclusion that while courts should not enforce the military order to detain Japanese-Americans on the West Coast, he did not mean to "suggest that courts should have attempted to interfere with the Army in carrying out its task."36

Or suppose that the consequence of a ruling consistent with $1 \mathrm{~A}$ would be merely to hasten a result that would have taken place without the Court's invalidation, while also heightening political polarization, promoting the electoral prospects of those who reject

\footnotetext{
${ }^{29}$ See Scalia, supra note 13.

3016 U.S.C.A. §§1531-1544 (West 2000 \& Supp. 2004).

${ }^{31}$ Cf. TVA v. Hill, 437 U.S. 153 (1978).

32 U.S.C. §\$2000d-2000d-7 (2000).

${ }^{33}$ Cf. Steelworkers v. Weber, 443 U.S. 193 (1979).

${ }^{34}$ See infra.

${ }^{35}$ For an overview, see Larry Alexander, Deontology at the Threshold, 37 SAN DiEgo L. REV. 893, 898901 (2000).

${ }^{36}$ See Korematsu v. United States, 323 U.S. 214, 248 (1944) (Jackson, J., dissenting).
} 
same-sex marriage, increasing hostility to gays and lesbians, and eventually leading to a constitutional ban on same-sex marriage. In this way, a ruling consistent with 1A would prove self-defeating in the particular sense that it would greatly decrease the likelihood that same-sex marriages would ultimately be recognized. Even a committed Kantian adjudicator might well hesitate to rule in the way indicated by $1 \mathrm{~A}$.

The second and more fundamental reason is that the principle of Kantian adjudication does not make much sense. The core Kantian claim is that people should be treated as ends, not as means. ${ }^{37}$ One person should not lie to another, or trick another into doing his bidding, because lies and tricks treat people as mere means, and do not give them the respect that they deserve. Is Kantian adjudication necessary to ensure that people are treated as ends rather than as means? It is hard to see why. In the end, Kantian adjudication is best understood as a kind of moral heuristic, ${ }^{38}$ justified on ruleconsequentialist or systemic grounds. The claim must be that certain people in certain roles ought not to consider certain consequences, because consideration of such consequences would likely lead to bad consequences. If, for example, the Supreme Court decided voting rights cases by asking whether one or another decision would have good consequences by helping the best political candidates, the social consequences would not likely be good. In short, the intuitive judgment that certain consequences, or all consequences, are off-limits to certain officials must be justified on consequentialist grounds. But to say that is to get ahead of the story.

\section{Consequentialism}

Suppose Bentham believes that acts must be evaluated by asking whether they produce good consequences, all things considered. At first glance, the commitment to consequentialism means that Bentham had better take account of the effects of the Court's decision. If Bentham has a reliable crystal ball, and he is sure that public outrage will ensure serious adverse effects from rulings consistent with $1 \mathrm{~A}-1 \mathrm{~F}$, those effects must be taken into account. Let us stipulate that Bentham's theory of constitutional interpretation, putting public outrage to one side, is itself based on consequentialist

\footnotetext{
${ }^{37}$ For a good discussion, see Christine Korsgaard, The Right to Lie: Kant on Dealing with Evil, 15 PHIL. \& Pub. AfF. 325 (1986).

${ }^{38}$ See Cass R. Sunstein, Moral Heuristics, 28 BeHAv. \& BRAIN SCI. 531 (2005).
} 
considerations. ${ }^{39}$ If Justice Bentham is a consequentialist, of course, he will not be much interested in public outrage as such. The question is whether that outrage will produce bad effects. If so, it would be seem especially odd for him to refuse to consider public outrage to the extent that it bears on the consequences of one or another ruling.

We might imagine three reasons that outrage might lead to bad consequences. ${ }^{40}$ First, it may render a judicial decision futile. Suppose, for example, that in 1954, a ruling in favor of immediate desegregation would simply be ignored. An argument in favor of the "all deliberate speed" formulation in Brown v. Board of Education ${ }^{41}$ was that it was necessary to ensure that desegregation would actually occur and that the Court's ruling would ultimately be obeyed. ${ }^{42}$ Second, outrage might make a judicial decision perverse, in the sense that it might produce consequences that are the opposite of what was intended by the Court. In the political domain, it is easy to think of illustrations, as when an environmental regulation, imposed on new polluting sources, turns out to increase pollution by increasing the life and use of old polluting sources. ${ }^{43}$ In the legal domain, we can imagine how a decision in 1962 requiring states to recognize racial intermarriage might have fueled resistance to racial desegregation and thus disserved the goal of ensuring compliance with the Equal Protection Clause in general. ${ }^{44}$ Third, outrage may render a judicial decision neither futile nor perverse, but might produce overall harm, as when the Court vindicates a constitutional principle in such a way as to endanger national security. ${ }^{45}$ Some people believe that judges rightly interpret the Constitution with an eye

\footnotetext{
${ }^{39}$ A straightforwardly consequentialist argument in favor of a particular approach to interpretation can be found in STEPHEN BREYER, ACTIVE LIBERTY (2005).

40 I borrow here from Albert O. Hirschman, The Rhetoric of Reaction: Perversity, Futility, JEOPARDY (1991).

${ }^{41} 349$ U.S. 294, 301 (1955).

${ }^{42}$ The ruling was of course very controversial. For illuminating discussion, see KLARMAN, supra note 3; Richard Kluger, Simple Justice (2d ed. 2004); and J. HARVIE Wilkinson, From Brown to BakKe (1979).

${ }^{43}$ See Howard Grenspecht, Zero Emissions Vehicles: A Dirty Little SeCret (2000), available at http://www.aei.brookings.org/publications/abstract.php?pid=92 (contending that requirement of lowpolluting new vehicles will actually increase pollution in short-run, by extending life of older, highpolluting vehicles).

${ }^{44}$ See Naim v. Naim, 350 U.S. 985 (1956) (declining to decide whether bans on racial intermarriage are unconstitutional). There are of course difficult issues about how to characterize the underlying goals, such that a particular decision would turn out to be perverse.

${ }^{45}$ This is the fear in Justice Jackson's dissent in Korematsu v. United States, 323 U.S. 214, 248 (1944), and probably in the Court's opinion as well, see id. at 220 ("when under conditions of modern warfare our shores are threatened by hostile forces, the power to protect must be commensurate with the threatened danger”).
} 
toward consequences, and in particular so as to ensure that national security is not threatened by their rulings. ${ }^{46}$

1. Assessing consequences. An immediate problem for Bentham is that by itself, the idea of consequentialism is insufficiently informative. It does not tell us how to weigh the potential consequences or even to tell whether certain outcomes are good or bad. ${ }^{47}$ Suppose, as seems plausible, that Roe v. Wade ${ }^{48}$ led to a great deal of political polarization, which would not have occurred if the Court had refused to recognize a right to choose abortion or if the Court had proceeded more cautiously. ${ }^{49}$ If so, did Roe therefore have bad consequences on balance? That question cannot be answered without assigning weights to its various effects, including immediate legalization of most abortions in the United States. It is also possible that Bentham will conclude that for good consequentialist reasons, some consequences should not be considered. Bentham might ultimately adopt a form of second-order or rule-consequentialism, through which he blinds himself to certain effects of his decisions.

To see the difficulties here, suppose that in a case involving same-sex marriage, Bentham has three options: (1) vote in accordance with 1A, (2) refuse to rule on the merits, or (3) vote to uphold bans on same-sex marriage. Perhaps Bentham thinks that if he takes the first course, same-sex marriage will be outlawed by constitutional amendment, raising a risks of both futility and perversity. Perhaps Bentham knows that if he refuses to rule on the merits, same-sex marriage will be widely permitted in the United States, and sooner rather than later. Perhaps Bentham believes that if he votes to allow bans on same-sex marriage, legislation allowing same-sex marriages will actually be passed very quickly; the Court's unfortunate ruling will actually promote the achievement of a situation that (in Bentham's view) the Constitution now requires.

How should Bentham assess this possibility? Perhaps Bentham believes that as a matter of principle, same-sex marriages ought to be recognized in a free society. But perhaps Bentham believes only that the existing Constitution is best interpreted to require states to recognize such marriages - and that it is also perfectly legitimate, and entirely

\footnotetext{
46 See Richard A. Posner, Not A Suicide PACT (2006) (arguing for pragmatic approach to the Constitution in the context of national security, in a way that allows the executive wide room to maneuver).

47 See DWORKIN, supra note 13.

48410 U.S. 113 (1973).

49 See Gerald Rosenberg, The Hollow Hope (1999).
} 
appropriate, for a constitutional amendment to disallow same-sex marriages. Whether the prospect of such an amendment counts as a bad consequence cannot be resolved unless Bentham makes supplemental judgments of various sorts. Bentham might believe, for example, that an amendment is not a relevant consequence, because his own personal views about same-sex marriage are immaterial; his legal judgments matter, not his personal views. If this is his belief, then there is no risk of either perversity or futility. Bentham might be willing to consider public outrage in deciding on the appropriate remedy for a constitutional violation, if outrage is relevant to the effectiveness of any such remedy. But if outrage will culminate in an amendment, perhaps Bentham need not and should not pay attention. If this is so, it is because the ultimate fate of same-sex marriage is none of his concern. This is a plausible view, but it ultimately requires some kind of consequentialist defense - as, for example, in the view that judges will do best if they do not take account of the risk that their decisions will be rejected through amendment.

Even if Bentham's preferred ruling on 1A does not produce an amendment, perhaps that ruling will mobilize opponents of the rights or interests in question, and demobilize those who endorse those rights or interests, in a way that will disserve some of Bentham's deepest convictions. ${ }^{50}$ Perhaps the rulings will alter the nation's political dynamics, promoting the interests of one party and undermining the interests of another. Perhaps the ruling will have no such effects, but perhaps it will sharply increase political polarization, leading to a great deal of hostility between those who approve and those who disapprove of the Court's decision. ${ }^{51}$ Bentham must decide whether these consequences matter and, if so, how much weight to assign to them.

There is another consideration, one that involves the Court's own "capital.” And indeed, most discussion of the "passive virtues," and of judicial caution in imposing itself on the public, has been focused on this consideration. ${ }^{52}$ Perhaps the ruling will increase public attacks on the Court, making the judiciary a salient target in elections and spurring jurisdiction-stripping bills and other legislative efforts to reduce the Court's authority and

\footnotetext{
${ }^{50}$ See id.

${ }^{51}$ See Mary Ann Glendon, Abortion and Divorce in Western Law (1989) (arguing Roe v. Wade produced polarization that reduced possibility of compromise solutions).

${ }^{52}$ See, e.g., BICKEL, supra note 2.
} 
independence. If the Court is concerned about its own place in the constitutional structure, and wants to maintain its power, it might take account of outrage as a method of self-preservation.

Or suppose more particularly that Bentham's crystal ball tells him that if he vindicates proposition 1A, same-sex marriages will occur, and be respected, in all states; that the nation will have an intense and hostile debate about the question; that the Republican Party will greatly benefit from the debate; and that a proposed constitutional amendment to ban same-sex marriages will ultimately fail. How is Bentham to assess these consequences? Perhaps he does not consider these consequences especially bad. Perhaps his commitment to the underlying principle is sufficiently strong that he is prepared to vindicate it so long as same-sex marriages will occur and be respected and so long as the proposed amendment will fail. Perhaps the increase in polarization, and the political consequences, are not sufficient to outweigh the desirable consequences that would follow from the ruling he favors. The simple point is that even if outrage leads to unintended or harmful consequences, Bentham cannot know that he should avoid outrage, because the good consequences might nonetheless outweigh the bad ones.

Or suppose Bentham's crystal ball shows that if he vindicates proposition 1D, capital punishment will cease in the United States for a long time; that the nation will have an intense and hostile debate about the question; that the Republican Party will greatly benefit from that debate; that a proposed constitutional amendment to allow the death penalty will ultimately fail; and that the Court itself will be subject to extremely harsh attacks for at least a decade. How should these consequences be assessed? Perhaps Bentham's commitment to the abolition of capital punishment, on grounds of constitutional principle, is very strong, and perhaps nothing in this catalogue of consequences outweighs that commitment. Why should human beings be executed, in violation of constitutional commands, merely because the nation will be more polarized, some politicians will win and others will lose, and the Court itself will come under assault?

As I have suggested, Bentham might believe that certain consequences-such as the prospect of a constitutional amendment or the favorable effects on one or another party_ought not to be counted at all. This conclusion would itself have to be explained 
on consequential grounds. If one party would produce better consequences than another party, is it so clear that consequentialist judges should ignore that fact? (What if a particular outcome would ensure the defeat of the Nazi Party?) Under ordinary circumstances, consequentialists should be prepared to accept a second-order constraint on judicial consideration of political effects, on the ground that the overall consequences would be bad if judges asked whether their rulings would favor one or another political party. ${ }^{53}$ Perhaps the same conclusion ought to hold for consideration of whether a constitutional amendment would ensue, on the ground that the overall consequences would be better if judges did not consider that question.

The most general point is that the consequentialist needs an account of value to know whether the various consequences are good or bad, and to know the magnitudes to the various effects. The difficulty and contentiousness of the assessment might well lead courts to adopt a general presumption or even a firm rule against considering the effects of public outrage. But let us simply stipulate that in some cases, of which $1 \mathrm{~A}-1 \mathrm{~F}$ are plausible examples, consideration of consequences will tip the balance against deciding the case in accordance with the principles to which Bentham otherwise subscribes.

2. Interpretive theories and consequences. This conclusion raises an immediate puzzle: What is the theory of interpretation that gives rise to Bentham's conclusions in cases $1 \mathrm{~A}-1 \mathrm{~F}$ ? Is it a consequentialist theory? Does Bentham hold it because of its consequences? A consequentialist had better give an affirmative answer.

To come to terms with this point, we should distinguish between Bentham's theory of interpretation and Bentham's theory of adjudication. We could imagine a judge who has a consequentialist theory of both interpretation and adjudication, that is, whose view about constitutional interpretation depends on the consequences, and who is alert to consequences in deciding how, exactly, to rule. Justice Stephen Breyer and Judge Richard A. Posner appear to fall in this category. ${ }^{54}$ Their accounts of interpretation are based on consequences, and they also think that judges should attend to consequences in

\footnotetext{
${ }^{53}$ Compare the debate over Bush v. Gore; no one contended that a member of the Court could legitimately take account of a judgment about whether George Bush or Al Gore would be a better president. It is interesting that pragmatic judges, insistent on taking account of consequences, implicitly ruled that consideration entirely out of bounds. See Richard Posner, Bush v. Gore (2001). The puzzle for the committed consequentialist is: Why?

${ }^{54}$ See BREYER, supra note (invoking consequences to assess theory of interpretation); RICHARD POSNER, LaW, Pragmatism, AND Democracy (2003) (same).
} 
particular cases. ${ }^{55}$ By contrast, we could imagine a judge who has a nonconsequentialist theory of interpretation, believing (for example) that originalism is the only plausible approach, ${ }^{56}$ but also agreeing that consequences matter when a judge is deciding whether and how broadly to rule. We could imagine a judge who believes that consequences are irrelevant both to interpretation and to adjudication. We could even imagine a judge who adopts a theory of interpretation on consequentialist grounds, but who believes that consequences are irrelevant to judicial rulings, once the appropriate method is applied. ${ }^{57}$

It should be clear that Bentham is not an originalist; but why not? Suppose that Bentham rejects originalism because in his view, it would produce unacceptable consequences. ${ }^{58}$ Suppose that Bentham also believes that the Court should usually be reluctant to strike down acts of the elected branches, because a presumption of validity will lead to good consequences. ${ }^{59}$ Suppose finally that the other ingredients of Bentham's own approach to interpretation are somewhat eclectic. Perhaps he is inclined to require the executive to be able to show clear legislative authorization for many actions involving national security. ${ }^{60}$ Perhaps he believes that the Court properly takes a somewhat aggressive role in protecting traditionally disadvantaged groups and in protecting the most intimate of choices. ${ }^{61}$ Suppose that Bentham is ultimately prepared to justify his approach, however eclectic it may be, in terms of its consequences. If so, consideration of public outrage seems at first glance reasonable and perhaps even obligatory, at least if that outrage would lead to bad consequences.

3. Judicial fallibility in assessing consequences: of rule-consequentialism and system design. If Bentham sits on the Supreme Court, however, he might well be nervous about certain forms of consequentialism. Let us relax a central assumption and assume that Bentham has no crystal ball. He likes to think that he is not at sea in deciding

\footnotetext{
55 See BreYer, supra note; Richard Posner, The Supreme Court, 2004 Term-Foreword: The Political Court, 119 HARV. L. REV. 31, 90-102 (2005).

${ }^{56}$ See Saikrishna Prakash, Radicals in Tweed Jackets: Why Extreme Left-Wing Law Professors are Wrong for America, 106 ColuM. L. REV. 2207 (2006).

${ }^{57}$ See Gunther, supra note 6, for an account of why this view might be coherent.

58 See BREYER, supra note.

59 See VERMEULE, supra note.

${ }^{60}$ See Richard Pildes \& Samuel Issacharoff, Between Civil Libertarianism and Executive Unilateralism: An Institutional Process Approach to Right During Wartime, Vol. 5, THEORETICAL INQUIRIES IN LAW (ONLINE EDITION): No. 1, Article 1 (2004), http://www.bepress.com/til/default/vol5/iss1/art1.

${ }^{61} \mathrm{See}$ JAMES FlEMing, SECURING THE CONSTITUTION (2006).
} 
whether the public will be outraged, and he has a degree of confidence in his judgments about the likely consequence of that outrage in particular cases. But Bentham knows that he may be wrong. He is entirely alert to human fallibility, and he is aware that even if his own judgments are fairly good, others are not so lucky. There are two independent problems here. The first is a simple lack of information. A projection of the existence of outrage may be a shot in the dark. A projection of the effects of outrage may be more speculative still, not least because judges may rely on information sources that are themselves unrepresentative and therefore biased. The second problem is motivational. Desires can influence judgments, ${ }^{62}$ and judges who favor certain results, or who are generally self-protective, may make erroneous judgments about the likelihood and effects of outrage.

Suppose that in light of the absence of crystal balls, Bentham thinks that consideration of the risk of public outrage will seriously complicate judicial judgments, without at the same time improving them from the consequentialist standpoint. ${ }^{63}$ Bentham would be inclined to consider the following view: Even if accurate judgments about public outrage would be, at least in extreme cases, a legitimate part of judicial thinking, the risk of error means that courts should not consider public outrage at all. Consideration of outrage makes judicial decisions more difficult and unruly. And in the end, consideration of outrage might make decisions worse, not better, on consequentialist grounds. Suppose that judges will exaggerate outrage or see it when it does not even exist. Suppose that judges will exaggerate the effects of outrage even when it does exist. Perhaps the natural human tendency toward self-protection will make judges risk-averse with respect to outrage; perhaps they will give undue weight to the possibility that the Court will be sharply criticized in public (not itself an especially bad consequence).

Suppose too that because public attacks on the judiciary will be especially salient to judges, consideration of outrage would produce undue timidity, in a way that will make judges less likely to do what they ought to do. Suppose that the role of an independent judiciary would be seriously undermined by consideration of outrage. On

\footnotetext{
${ }^{62}$ An illustration is "confirmation bias," by which people's judgments about what is true are influenced by their desire to have their own beliefs confirmed. See, e.g., Barbara O'Brien \& Pholbe Ellsworth, CONFIRMATION BIAS IN CRIMINAL INVESTIGATIONS (2006), available at http://papers.ssrn.com/sol3/papers.cfm?abstract_id=913357.

${ }^{63}$ See Gunther, supra note 6.
} 
rule-consequentialist grounds, Bentham would be willing to consider a prohibition on judicial consideration of public outrage. History suggests that Bentham would be right to do exactly that; in the domain of free speech, judges have tended to overestimate the adverse consequences of allowing the airing of dissenting views, especially in wartime. ${ }^{64}$ If judges consider outrage and its effects, they may exaggerate the problem, thus adding to the excessive caution that judges might already feel when the stakes, and the heat, are high. ${ }^{65}$

There is another possibility. Bentham might ultimately reject the ruleconsequentialist argument on the ground that he is only one person and hence powerless to ban consideration of outrage on his own. Even if this is so, a social planner, engaged in system-wide design, might support that ban. Such a planner might attempt to inculcate a strong norm, or even a taboo, against judicial consideration of outrage. Consider the question whether judges should ask whether one or another political party would be benefited by a judicial decision. In most imaginable circumstances, a social planner would not want judges to ask that question; consideration of the political consequences would make the legal system much worse. Perhaps a similar argument justifies a general ban on consideration of public outrage, especially if judges cannot reliably assess the question of consequences. If they cannot do so, consideration of outrage may increase the burdens of decisions while also leading, on balance, to worse results.

The rule-consequentialist argument certainly cannot be ruled out of bounds a priori. But it is not at all clear that this argument can be made convincing, at least not in the abstract. Even if judges have fallible tools for considering public outrage, they are not wholly at sea. If the Court invalidated the use of the words "under God" in the Pledge of Allegiance, public outrage would be entirely predictable; so too if the Court required states to recognize same-sex marriage; so too if the Court dramatically restricted Congress' powers under the Commerce Clause. At least in cases in which outrage and its consequences are easily foreseen, it is hard to rule its consideration off-limits on ruleconsequentialist or systemic grounds. Cases $1 \mathrm{~A}$ through $1 \mathrm{~F}$ are plausible examples.

\footnotetext{
${ }^{64}$ See Z. Chafee, Free Speech in the United States (1941); Geoffrey R. Stone, Perilous Times (2005).

${ }^{65}$ Cf. Scalia, supra note 13, at 1180 (emphasizing the value of rules in allowing judges to stand firm when popular pressure is intense).
} 
The conclusion is that for consequentialist reasons, widespread public outrage is a legitimate consideration where it would produce serious harm; it is appropriate for judges to limit the reach of their holdings, or to decline to decide certain issues, if such harm would be likely to occur. If this conclusion is not especially surprising in light of actual practice, all the better; we are now in a position to understand the grounds for that practice, and also the grounds on which it might be criticized.

4. Kantian adjudication revisited and some speculations about institutional morality. Let us return in this light to Kantian adjudication, captured in the view that judges should pay no attention to the risks of futility, perversity, or overall harm. Compare those who exercise the social role of doctors. In deciding what treatments to prescribe, doctors do not and should not ask whether extending the life of a particular patient will produce good consequences. Doctors are not permitted to prescribe ineffective treatments or to hasten death on the ground that the world would be better if certain patients died. Nor is it appropriate for lawyers, representing especially bad people, to collude with the prosecution to ensure a conviction and a stiff sentence. Defense lawyers are obliged to provide the best possible defense, and are not supposed to assess, in particular cases, whether the consequences might not be better if their clients were convicted. ${ }^{66}$

Perhaps judges are analogous. Perhaps their social role requires them to rule consideration of certain consequences off-limits. Perhaps judges should think in the following way: My job is to do as the law requires. In the most extreme cases, I might consider resigning from the bench, or I might consider engaging in a form of civil disobedience. But while exercising judicial power, my sole responsibility is to the law.

As we shall see, a central problem with this view is epistemic: Judges might be unsure what the law requires, and public outrage might be relevant to that question. But the deeper problem is that a consequentialist justification is required for most judgments about what is appropriately considered by either private or public actors. Institutional morality, and role morality more generally, must be defended in terms of its effects. The

\footnotetext{
${ }^{66}$ See Richard Wasserstrom, Lawyers as Professionals: Some Moral Issues, 5 HumAn RighTs 1, 6 (1975) (noting that once a lawyer-client relationship with a criminal defendant is established it is "appropriate and obligatory" for the attorney to put on a vigorous defense even if the attorney believes the client to be guilty).
} 
reason that lawyers should not ask themselves about the consequences of helping a particular client is that the legal system, taken as a whole, is better if lawyers do not so inquire. To be sure, the question is not identical for doctors. Human beings should be treated as ends rather than means, and there is a legitimate Kantian objection to a medical decision to hasten a patient's death on consequentialist grounds. ${ }^{67}$ But consequentialists, as such, can agree that people should be treated as ends; treating people as means is a part of the set of (bad) consequences that count. ${ }^{68}$ In any event, judges are more closely analogous to lawyers than to doctors. If their decisions really would be futile or perverse, or produce overall harm, they should take those possibilities into account—unless ruleconsequentialist arguments convincingly suggest otherwise. Kantian adjudication, and the distinction between following the law and civil disobedience, are best understood as products of rule-consequentialism.

There is a broader point here about the moral obligations of those who find themselves in certain social roles. Nearly every public institution is barred from taking account of certain considerations that ought to matter from a consequentialist perspective. Jurors are not supposed to ask whether a particular verdict would contribute to an increase in Gross National Product or find a favorable reception among most of their fellow citizens. Panels for the National Academy of Sciences are asked to say what is true, whatever the consequences, and it would be outrageous to ask such a panel to distort scientific findings in order to avoid public outrage. Members of public institutionsincluding juries, National Academy of Sciences panels, and regulatory agencies-are not supposed to ask whether one or another conclusion would help their preferred political party, even if members of such institutions believe that the consequences would be much better if their preferred party were helped.

The ban on consideration of certain factors often operates as a moral taboo; but why? In most settings, the overall consequences are much better if institutions refuse to take account of certain consequences. A virtue of assessing institutional morality in this

\footnotetext{
${ }^{67}$ Cf. Carol Steiker, No, Capital Punishment Is Not Morally Required, 58 StAn. L. Rev. 751 (2005) (objecting to convictions of innocent people, even if consequentialism called for such convictions).

${ }^{68}$ See Sen, supra note, 1038-39.
} 
way is that it permits us to explore whether, in fact, any particular taboo can be justified in consequentialist terms. ${ }^{69}$

5. Judicial hedometers and consequentialism writ (very) large. Outrage is an extreme reaction to a judicial ruling, and it is distinctly associated with a risk of bad consequences. But it is easy to imagine other reactions. Perhaps people would not be outraged; perhaps they would be disgusted, dismayed, frustrated, or disappointed. Alternatively, they might have a range of positive reactions to a ruling. They might be happy, gratified, relieved, thrilled, or exhilarated. Perhaps those positive reactions will produce an array of valuable consequences. ${ }^{70}$ If the Court invalidated certain restrictions on the rights of property owners, surely many property owners would be pleased, ${ }^{71}$ and their positive reactions might have desirable economic effects. (Perhaps the consequences would be good for economic growth.) When the Court struck down the ban on same-sex relations, ${ }^{72}$ many people were undoubtedly elated.

Suppose that all judges had a well-functioning "hedometer"-a device that could produce accurate measures of people's affective reactions to judicial decisions. Should judges consider the hedonic consequences of their rulings, either in themselves or because of their eventual effects? Or suppose that judges could consult contingent valuation studies, in which people stated their willingness to pay for certain judicial

69 Compare Bernard Williams' well-known suggestion that in certain domains, those who make consequentialist assessments have "one thought too many." If someone makes such an assessment before deciding to save his wife rather than a stranger from a burning building, we might well conclude that he is having an excessive thought. See Bernard Williams, Persons, Character, and Morality, in MORAL LucK 18 (1981). So too, it might be thought, for those in certain institutional roles. If a doctor asks whether a patient is benefiting society before undertaking a diagnosis, or if a judge thinks about the consequences for the unemployment rate of a certain ruling, excessive thinking is taking place. It is worth considering the possibility that Williams' claim is correct, but only for reasons of system design: The consequences are best if spouses do not think that way, and so too for doctors and judges. For a critique of Williams' position, see Elinor Mason, Do Consequentialists Have One Thought Too Many?, 2 ETHICAL THEORY AND Moral PRACTICE 243 (1999).

${ }^{70} \mathrm{Cf}$. Breyer, supra note (defending validation of affirmative action on the ground that it would promote inclusion and active democracy). Justice Breyer's point is not that the reaction to the Court's decision would itself produce good consequences, but it is certainly a consequentialist defense of the validation of affirmative action.

${ }^{71}$ Compare the public reaction to Kelo v. City of New London, 545 U.S. 469 (2005). President Bush, for example, reacted to the decision with an executive order instructing the federal government to use eminent domain "...for the purpose of benefiting the general public and not merely for the purpose of advancing the economic interest of private parties to be given ownership or use of the property taken.” Exec. Order No. 13,406, 71 FED. REG. 36973 (June 23, 2006), available at http://www.whitehouse.gov/news/releases/2006/06/20060623-10.html.

${ }^{72}$ See Lawrence v. Texas, 539 U.S. 558, 578 (2003). 
decisions. ${ }^{73}$ People are willing to pay significant amounts to ensure the existence of pristine areas and animals; "existence value" is an established part of the practice of contingent valuation. ${ }^{74}$ Surely people would also be willing to pay significant amounts to ensure the existence of certain legal outcomes; these too have an existence value. Ought judges to pay attention to any relevant evidence? Such questions seem fanciful, but it is important to figure out why.

For the committed consequentialist, it is tempting to answer that judges should consider all relevant consequences, not merely those associated with outrage. Negative feelings are themselves a social loss, ${ }^{75}$ and positive feelings are a social gain. And if negative feelings would result in adverse effects, they should certainly count. A political leader, deciding whether to support a proposed bill, might well be influenced by negative reactions of this kind, not only because her reelection prospects might be affected, but also because she is a considered consequentialist. If judges have crystal balls, and are therefore able to make perfect forecasts, the consequentialist judgment would seem to be that they should reach the same conclusion, considering not merely outrage, but the full array of effects of their decisions.

But for rule-consequentialist reasons, and from the standpoint of system design for real-world judges, that conclusion would be hard to defend. It is an understatement to say that judges lack reliable methods for measuring the hedonic effects of their rulings. Any attempt to try would undoubtedly be subject to distortions. There are also questions about whether all hedonic effects should count in the social welfare calculus, independently of whether they should count in the judicial calculus: If people would be pleased at the continuation of torture or discrimination, does their pleasure count? ${ }^{76}$ If judges attempted the relevant measurement, and made its outcome relevant in hard cases, the consequences would probably be worse, not better. If judges should care at all about public reactions, the argument for doing so is strongest in the case of outrage, because

\footnotetext{
${ }^{73}$ See Stephen Breyer et Al., Administrative Law and Regulatory Policy 335-36 (6th ed. 2006).

${ }^{74}$ See Ian BATEMAN ET AL., VALUing ENVIRONMENTAL PREFERENCES (1999).

${ }^{75}$ See Matthew Adler, Fear Assessment: Cost-Benefit Analysis and the Pricing of Fear and Anxiety, 79 CHI.-KENT L. REV. 977, 987-89 (2004) (describing how a particular negative feeling — fear — is a welfare setback and should be counted as a cost in cost-benefit analyses).

${ }^{76}$ For discussion with relevant citations, see LOUIS KAPLOW \& STEVEN SHAVELL, FAIRNESS Vs. WeLFARE (2005).
} 
outrage is likely to produce the most damaging consequences. The effects associated with other hedonic states are exceedingly difficult to predict.

\section{E. Consequentialist Hesitations}

With respect to public outrage and its effects, we are left with two possible conclusions. Perhaps Kantian adjudication is ultimately right, because blindness to consequences is likely to produce the best consequences. This conclusion might be defended on several grounds. First, courts lack reliable tools for deciding whether outrage and adverse effects would be present; they might well produce false negatives and false positives, Second, consideration of outrage would undoubtedly lead to strategic behavior, making outrage partly endogenous to the Court's willingness to take it into account. If people are aware that their outrage will affect the Court, then they will have every reason to produce outrage, creating a kind of heckler's veto. Third, consideration of outrage might produce undue timidity, especially in areas in which the Court's role is most important. If widespread outrage is understood to be a legitimate reason for the Court to fail to act, then the Court will uphold government decisions that, by hypothesis, violate the Constitution, simply because people are outraged at what the Constitution commands. If the document is taken as a kind of precommitment strategy, ${ }^{77}$ designed to check certain actions however intensely supported at any moment in time, then consideration of outrage will produce bad consequences, once those consequences are properly understood and weighted.

But another conclusion is possible, and it too is reasonable: In extreme cases, judges have sufficient information to know whether outrage will exist and have significant effects, and in such cases they rightly hesitate before imposing their view on the nation. This was Bickel's position about certain controversial rulings in his era, ${ }^{78}$ and it helps to explain the view that the Court was right not to invalidate the ban on racial intermarriage in the $1950 \mathrm{~s}^{79}$ and wrong to rule so broadly on the abortion question in the

\footnotetext{
77 See STEPHEN Holmes, PASSIONS AND CONSTRAint (1999).

${ }^{78}$ See BICKEL, supra note 2, at 174-75.

${ }^{79}$ See Naim v. Naim, 350 U.S. 985 (1956).
} 
early 1970 s. $^{80}$ It is easy to imagine analogues today, including invalidation of bans on same-sex marriage, a large-scale expansion of the takings clause, ${ }^{81}$ a constitutional attack on references to God in currency and in the Pledge of Allegiance, and sharp limitations on congressional authority as, for example, through invalidation of popular environmental legislation. In at least some of these cases, consequentialist considerations do seem to justify a degree of judicial hesitation. I will offer more details below.

\section{Humility, Invalidations, and the Condorcet Jury Theorem}

Now let us relax a key assumption, involving not crystal balls but the judge's level of confidence. Let us suppose we are dealing not with Justice Bentham but with Justice Condorcet.

Suppose that Condorcet accepts propositions $1 \mathrm{~A}-1 \mathrm{~F}$, but he is not entirely certain that he is correct to do so. Let us stipulate that in these cases, Condorcet is aware that most officials and most citizens disagree with him about the appropriate understanding of the Constitution. If so, Condorcet might find anticipated public outrage relevant not for the reasons discussed thus far, but for an epistemic reason: Intense public opposition is a clue that his interpretation of the Constitution is incorrect. To make the argument most plausible, let us suppose that Condorcet's acceptance of propositions $1 \mathrm{~A}-1 \mathrm{~F}$ is inconsistent with the shared judgment of the President, almost all members of Congress, and the overwhelming majority of state and local officials and ordinary citizens. Condorcet might hesitate on grounds of humility; his own view about the Constitution's meaning might be wrong.

Of course Bickel, and those who share his confidence in judicial capacities, would have little sympathy for this argument. Recall that Bickel believed that by virtue of their insulation, judges are in a particularly good position to announce the enduring values that the Constitution should embody. ${ }^{82}$ To the extent that this belief is correct, judges do not have an epistemic deficit that would justify humility. But Bickel's confidence on this

\footnotetext{
${ }^{80}$ See Roe v. Wade, 410 U.S. 113 (1973); see also Ruth Bader Ginsburg, Some Thoughts on Autonomy and Equality in Relation to Roe v. Wade, 63 N.C. L. Rev. 375 (1985).

${ }^{81}$ See, e.g., RICHARD A. EPSTEIN, TAKINGS (1985) (calling for such an expansion).

${ }^{82}$ See supra TAN 20-22.
} 
count is certainly not universally held, indeed it seems strikingly unself-conscious; and sensible judges are aware of their own fallibility.

\section{A. The Basic Argument}

To understand the hesitation of the relevant justice, consider the Condorcet Jury Theorem (CJT). ${ }^{83}$ Suppose that members of some group are asked to resolve some question, and each member is at least more than 50\% likely to be right. The CJT says that as the size of the group expands, the likelihood that a majority of the group will be right approaches $100 \%$. The CJT helps to explain the "wisdom of crowds," 84 that is, the frequent and apparently magical correctness of large collections of people in making judgments of fact. ${ }^{85}$ If many people are asked some question of fact, with one right answer and one wrong answer, there is a strong likelihood that the majority will be right so long as all or most people are more than 50\% likely to be right. Technical work shows that a similar result holds for plurality judgments about questions with more than two possible responses. ${ }^{86}$

Here is a mundane example from the constitutional domain: Suppose that there is a dispute about the original understanding of some constitutional provision-say, about whether the Equal Protection Clause, as originally understood, forbids racial segregation. Suppose that Condorcet is interested in the original understanding and that he believes that the Equal Protection Clause was, in fact, originally understood to ban racial segregation. If it turns out that Condorcet's view is an outlier, and is accepted by almost none of those who have studied the relevant period, the CJT suggests that Condorcet is probably wrong. And if most specialists are outraged by Condorcet's conclusion, Condorcet has particular reason to hesitate on epistemic grounds.

Alert to the CJT, Condorcet might think the following: I accept propositions 1A1F. But most of the public disagrees with me. If crowds are wise, I may well be wrong, at least if the public's disagreement bears on an issue that is relevant to the legal conclusion.

\footnotetext{
${ }^{83}$ For a sketch, see Cass R. Sunstein, Infotopia: How Many Minds Produce Knowledge 25-28 (2006).

${ }^{84}$ See JAMES SuROWIEKI, THE WISDOM OF CROWDS (2004).

${ }^{85}$ An especially helpful discussion is SCOTT PAGE, THE DifFERENCE (2007).

${ }^{86}$ See Christian List \& Robert E. Goodin, Epistemic Democracy: Generalizing the Condorcet Jury Theorem, 9 J. POL. PHIL. 277, 283-88, 295-97 (2001).
} 
It might be useful to make a distinction here between judgments of fact and judgments of political morality. Suppose that Condorcet is not an originalist and that he believes that the constitutionality of capital punishment turns, in part, on whether that form of punishment has a deterrent effect. Suppose that the death penalty is constitutional only if it has a significant deterrent effect. On the basis of his own view of the evidence, Condorcet may doubt that there is any such effect. But if most people believe that capital punishment does, in fact, have a deterrent effect, then Condorcet might want to pay careful attention to their beliefs. Perhaps Condorcet is more interested in the views of specialists than in the views of the public at large; but if members of the public have some access to relevant information, the view of a strong majority might bear on the factual question.

By contrast, suppose that the constitutionality of the ban on same-sex marriage does not turn on disputed facts, but instead on a judgment of political morality. Suppose that the question is whether the grounds for discriminating against gays and lesbians, in the particular domain of marriage, are legitimate. Is the CJT irrelevant? It would be if we believe that moral judgments cannot be right or wrong. If we are moral relativists or skeptics, we will not have much interest in the idea of moral truth. But suppose we believe that such judgments are in fact subject to evaluation; if Condorcet's moral views are relevant to his legal conclusions, he had better share that belief. Even if a moral judgment is crucial, the views of the public might provide some clues about what morality in fact requires. If most people reject Condorcet's moral conclusions, he might worry that he is missing something or that his conclusions are wrong.

To come to terms with these possibilities, much will depend on the prevailing theory of constitutional interpretation. If Condorcet's theory is originalist, the views of the public might not much matter; as should be evident and as we shall see in more detail, those views are not likely to tell Condorcet much about the nature of the original understanding. (Nonetheless, the CJT suggests that he should be interested in the views of specialists.) But suppose, with Bickel and many others, ${ }^{87}$ that Condorcet's conclusions about the meaning of the Constitution do in fact depend on some judgment of political morality. If so, then the views of others might well be relevant. And indeed, the Court's

\footnotetext{
$\overline{{ }^{87} \text { See, e.g., DWORKIN, supra note } 13 .}$
} 
decision to strike down criminal bans on same-sex relationships had a great deal to do with its perceptions of contemporary social values, in a way that suggested an implicit Condorcetian logic. ${ }^{88}$

Suppose that Justice Condorcet believes that in cases $1 \mathrm{~A}-1 \mathrm{~F}$, he is obliged to try to bring forward the best justification, in principle, for the fabric of existing law. ${ }^{89}$ The public's views might provide valuable information about which justification is best. Of course Condorcet will not be much interested in those views if they are irrelevant to what matters under his theory of interpretation (a point to which I will return). A strong division between the domain of law and the domain of politics and morality would weaken and possibly eliminate the epistemic argument for attending to public outrage.

\section{B. Outraged, and What Are They Outraged About?}

To sharpen the question, we need to know what proposition, exactly, the public's outrage can be taken to affirm. The initial objection to the epistemic argument is that public outrage may not be related to any proposition in which Justice Cordorcet should be interested.

If the public is outraged by $1 \mathrm{~A}-1 \mathrm{~F}$, it is most unlikely to be motivated by its independent interpretation of the Constitution. The outrage is more likely to reflect a judgment about the actual social risks, speaking empirically, that would be created by (for example) same-sex or polygamous marriages or abolition of the death penalty, or about the social values, speaking in purely moral terms, that the existing practices promote. For the outrage to matter to the Condorcetian judge, it must be because the public's judgments on these points bear on, or overlap with, the judgments that give rise to constitutional interpretation. This is hardly unimaginable. Perhaps the public believes that there is a legitimate and weighty reason to ban polygamy, and perhaps that belief bears on the constitutional issue. Perhaps the public believes that under contemporary conditions, the President needs the authority to commit troops without congressional authorization, and perhaps that judgment of need is relevant to the meaning of the Constitution.

\footnotetext{
${ }^{88}$ See Lawrence v. Texas, 539 U.S. 558, 572, 576 (2003).

89 See RONALD DWORKIN, LAW's EMPIRE (1985).
} 
Or consider another possibility, involving not the public as such but a relevant segment of it. Perhaps Condorcet should focus not on the public, but on the outrage of prominent officials who are themselves charged with the duty of complying with the Constitution. Perhaps the executive branch, and many legislators, have a considered view about what the Constitution requires with respect to $1 \mathrm{~A}-1 \mathrm{~F}$. If the executive branch thinks that there is no constitutional problem with the death penalty, or that bans on polygamy are unobjectionable, then that view may be worth serious consideration. As I have suggested, a great deal depends on the appropriate constitutional method. If the executive operates on originalist premises, and if Condorcet rejects those premises, then the view of the executive and its level of outrage would appear to be neither here nor there. But suppose that Condorcet is not sure, in the end, of the appropriate constitutional method. On grounds signaled by the CJT, Condorcet should hesitate before rejecting a view, even about method, that is widely held. Perhaps Condorcet's judgment about method will be influenced by the majority of large groups of people; the CJT suggests that it ought to be. And if the widely held view depends on a method that he accepts, he might well attend to it.

Thus far I have assumed that the views of the public are relatively uniform, on the view that with that assumption, the epistemic argument for attention to outrage is most straightforward. But it is far more likely that the public will be divided. Suppose, for example, that thirty percent of the public agrees with $1 \mathrm{~A}$, that fifty percent disagrees, and that twenty percent is unsure; suppose that of those who disagree, only about two-thirds are genuinely outraged. Or suppose that for $1 \mathrm{~B}$, eighty percent disagree, twenty percent agree, and only eighty percent of those who disagree are outraged. In the face of divisions of this kind, judges will have far more difficulty in understanding whether the epistemic reasons for attention to public outrage are present. The CJT is helpful only when there is a consensus, or something close to it, on a relevant proposition from a group most of whose members are more than 50 percent likely to be right. I will return to this point below. 


\section{Biases and Cascades}

Sometimes widely held views are uninformative about what is true. If Americans were asked about the distance between Paris and Nigeria, the number of federal statutes invalidated by the Supreme Court, or the weight of the moon, there would be no particular reason to trust the majority's answer. If most people are likely to blunder, the average answer, or the majority answer, has no epistemic credentials. In the constitutional context, there is especially good reason to think that widespread public judgments deserve little weight.

1. Bias. Suppose, first, that judgments of the public are less than $50 \%$ likely to be right, as for example because of some kind of systematic bias. If so, the majority is not likely to right. On the contrary, the simple arithmetic behind the CJT shows that the likelihood that the majority will be wrong approaches $100 \%$ as the size of the group expands ${ }^{90}$ ! To see the point, begin with an area outside of the domain of constitutional law and suppose that most people underestimate the number of people who die from asthma attacks; let us suppose that the relevant deaths are not cognitively "available," and the availability heuristic biases their judgments. ${ }^{91}$ If so, it is senseless to ask what most people think. Because of a systematic bias, their judgments will be erroneous.

Now turn to the legal domain and consider the constitutional validity of statutory bans on racial intermarriage. It should hardly be controversial to suggest that public disapproval of racial intermarriage is a product of a systematic bias. Insofar as that disapproval bears on the constitutional issue, it is easily understood as biased in light of the relevant equal protection norms, in which Condorcet deserves to have confidence. Very plausibly, public disapproval of racial intermarriage stems from systematic biases with respect to facts as well as norms. Why should Condorcet pay attention to people's error-prone judgments?

The general problem is that if Condorcet has good reason to believe that most people suffer from a kind of prejudice that infects their judgments, he ought not to pay attention to what they think. And in fact, the real Condorcet emphasized that "prejudice"

\footnotetext{
90 See Sunstein, supra note, at 29-30.

91 See, e.g., Norbert Schwartz \& Leigh Ann Vaughn, The Availability Heuristic Revisited, in HeURISTICS AND BIASES 103 (Thomas Gilovich et al. eds. 2002).
} 
can introduce a distortion that makes his arithmetic unlikely to produce good results: "In effect, when the probability of the truth of a voter's opinion falls below $1 / 2$, there must be a reason why he decides less well than one would at random. The reason can only be found in the prejudices to which this voter is subject."92 Bickel's emphasis on the consequentialist grounds for concern with public outrage, and his failure to see the epistemic grounds, is best understood as a product of a belief that when the Court and the public diverge, the Court will be right and the public will be wrong. ${ }^{93}$ Perhaps Bickel was far too confident on this count; but we can easily imagine cases in which judges rightly distrust the public.

The question, then, is whether a bias might distort people's judgments with respect to $1 \mathrm{~A}-1 \mathrm{~F}$, in which case those judgments have no epistemic value. It would be entirely plausible for Justice Condorcet to worry about the risk of such a bias; $1 \mathrm{~A}$ and $1 \mathrm{E}$ are especially good candidates.

2. Cascades. The second problem is that people's judgments may be a product of an informational, moral, or strictly legal cascade, in which case they lack the independence that the CJT requires. ${ }^{94}$

a. Basic processes. In an informational cascade, most people form their judgments on the basis of the actual or apparent judgments of others. ${ }^{95}$ Consider a stylized example. Adams says that in her view, the death penalty deters. Barnes does not have a great deal of private information, but having heard Adams' belief, she agrees that the death penalty deters. Carlton would have to have reliable information in order to reject the views of Adams and Barnes - and he lacks that information. If he follows Adams and Barnes on the ground that their shared belief is likely to be right, Carlton is in a cascade. Davison, Earnhardt, and Franklin may well follow the shared views of Adams, Barnes, and Carlton, at least if they lack private information. ${ }^{96}$

\footnotetext{
${ }^{92}$ Condorcet, Selected Writings 62 (Keith Michael Baker, ed., Indianapolis: Bobbs-Merrill 1976).

${ }^{93}$ See BICKEL, supra note 2, at 23-28.

${ }^{94}$ See Eric Posner \& Cass R. Sunstein, The Law of Other States, 59 STAN. L. ReV. 131 (2006) (exploring view that courts should take into account decisions of other courts on Condorcetian ground that they provide valuable information).

95 See Sushil Bikhchandani et al., Learning from the Behavior of Others: Conformity, Fads, and Informational Cascades, 12 J. ECON. PERSP. 151, 167 (1998).

${ }^{96}$ For fascinating experimental evidence, see Robert C. Jacobs and Donald T. Campbell, The Perpetuation of an Arbitrary Tradition Through Several Generations of a Laboratory Microculture, $62 \mathrm{~J}$ Abnormal and
} 
It is easy to imagine moral analogues, ${ }^{97}$ in which Carlton follows Adams and Barnes, not because they independently agree, but because they do not have enough confidence in their antecedent moral views to reject the judgments of others. With respect to same-sex marriage, it is plausible to think that moral cascades are pervasive. Many people are outraged by same-sex marriage, not because of their own independent judgments, but because of the real or apparent moral convictions of trusted others. In the domain of terrorist behavior, the moral judgments that produce violence are typically a product of social influences; ${ }^{98}$ outrage is itself fueled and increased by such influences. There is no need to speculate about cascade effects on juries, for an experimental study found that jurors' level of outrage is greatly amplified as a result of deliberative processes. ${ }^{99}$ Outrage is demonstrably heightened by the outrage of others, so as to ensure that groups are far more outraged than were the individuals who compose them in advance of deliberation. ${ }^{100}$

b. Outrage cascade and meaning entrepreneurs. Informational and moral cascades might well be responsible for public outrage in response to a judicial ruling. Suppose, for example, that people believe that polygamy harms women, or that same-sex marriage is morally unacceptable, not because of any private information or even judgment, but because they are reacting to the informational signals given by others. We could readily imagine legal cascades as well, in which the public's constitutional judgments develop not on the basis of independent assessments of the merits, but in response to the actual or apparent legal judgments of others. Within the lower courts, such cascades do seem to develop among judges. ${ }^{101}$ If precedential cascades can be found within the court system, there is every reason to believe that legal cascades occur within the legal culture, or the public culture in general, as the constitutional judgments of a few

Social Psych 649 (1961); Gregory Moschetti, Individual Maintenance and Perpetuation of A Means/Ends Arbitrary Tradition, 40 Sociometrry 78 (1977).

97 See Stanley Cohen, Folk Devils and Moral Panics (rev. ed. 2002). Of course moral judgments might well be a product of relevant information, in which case moral cascades are informational cascades too.

${ }^{98}$ See Alan Krueger \& Jitka Maleckova, Education, Poverty, Violence, and Terrorism, 17 J. ECON. PerSP. 119 (2003).

${ }^{99}$ See David Schkade et al., Deliberating About Dollars: The Severity Shift, 100 Colum. L. Rev. 1139 (2000).

${ }^{100} \mathrm{Id}$.

${ }^{101}$ See Andrew F. Daughtety \& Jennifer F. Reinganum, Stampede to Judgment, 1 AM. LAW \& ECON. REV. 158 (1999). 
help to produce an apparently widespread view in favor of one or another position. If such cascades are widespread or enduring, they might even become self-confirming, as the widespread judgment becomes entrenched within the public and eventually within the law.

Cascades might be spontaneous or deliberately induced. Spontaneous cascades arise because a few early movers express their view in a prominent way; the early movers increase the salience of the Court's decisions and might eventually produce widespread outrage. Alternatively, political actors in the public or private sectors might work very hard to generate a cascade effect, using the popular media to generate a great deal of public opprobrium. It is easy to imagine "meaning entrepreneurs," who take it as their task to inculcate a certain view of constitutional meaning, and to spread that view far and wide. In either case, there is no particular reason to trust the apparent judgments of large groups on Condorcetian grounds. By hypothesis, such groups are responding to the beliefs of only a few. A precondition for deference to the wisdom of the crowd-a large number of independent judgments-is absent.

3. Hesitation and humility without the CJT. Most generally, and even without speaking of a systematic bias, Condorcet might well want to accept himself: Is it really the case that many or most members of the public are more likely than not to provide correct answers to legally relevant questions of fact and morality? If morality is pertinent to constitutional adjudication, Condorcet might be puzzled by the suggestion that most people will answer the key questions correctly. Suppose that Condorcet is exploring some constitutional question associated with racial segregation, free speech in a time of war, the Establishment Clause, or discrimination on grounds of sexual orientation. WhyCondorcet might wonder-should I believe that most people are more than 50 percent likely to provide the right answer to the underlying question?

If Condorcet cannot answer this question, and hence finds the CJT irrelevant, he might nonetheless hesitate on epistemic grounds before rejecting the views of the majority. He might believe that the issue is comparative: Is the public more likely, or less likely, to be right than are federal judges? ${ }^{102}$ Does the answer to this question change if the public is genuinely outraged? If Condorcet is an originalist, he will be confident that

\footnotetext{
102 See PAGE, supra note.
} 
the public's views do not much matter. If he follows Bickel, and thinks that judges have unique ability to discern evolving values, he will not be much interested in what the public thinks. We can therefore find a temporary epistemic alliance (truce?), in rejecting the views of the public, between originalists and many of those who believe that the Constitution's meaning evolves over time.

But Condorcet might observe that the Court consists of nine lawyers-mostly white, mostly male, mostly wealthy, and mostly old (or at least not young). In light of that fact, he might believe that judges are at an epistemic disadvantage in answering some important questions-perhaps because of their relative lack of diversity, ${ }^{103}$ perhaps because they are the ones who are likely to suffer from a systematic bias. If Condorcet thinks in this way, and if he believes that judgments of fact or morality bear on constitutional meaning, he might well be interested in the widely held views of the public. $^{104}$

\section{A Practical Problem and a Conclusion}

In theory, these points are straightforward. In practice, they create serious problems for those who invoke epistemic grounds for considering public outrage. Suppose that Condorcet is a humble judge, alert to his own fallibility, who wants to consider the views of others unless there is a systematic bias or some kind of cascade effect. Condorcet must decide whether a bias or a cascade is at work. Suppose, first, that he has unerring tools for making that decision. If so, there is no particular problem; he knows when the circumstances are right for consulting the public's view. But if Condorcet really does have such tools, he probably knows a great deal, and he might well be able rely on his own judgment. If so, he need not worry about what other people think.

Suppose, as is far more realistic, that he lacks such tools. To know whether the public suffers from a relevant bias or thinks as it does because of a cascade, Condorcet has to answer some hard questions - conceptual, normative, and empirical. As a judge, he will likely lack the tools to answer them well. Realistically, his own views about the merits, in cases $1 \mathrm{~A}-1 \mathrm{~F}$, will undoubtedly influence his answers. If most people disagree

\footnotetext{
103 See id.
}

${ }^{104} \mathrm{Id}$. 
with him, he is likely to conclude that they do, in fact, suffer from some kind of bias. There is a pervasive risk that any judge, asking whether the preconditions for collective wisdom are met, will answer the question affirmatively only when he already agrees with what people think.

Let us imagine that Condorcet can overcome this problem and approach the underlying questions in an acceptably neutral way. Is it possible for him to know when a bias or a cascade is at work? In the abstract, we can imagine how he might make progress on that question. Perhaps his theory of interpretation permits him to consider certain judgments to be "biases" in a constitutionally relevant sense. Perhaps he believes that if most people oppose racial intermarriage, or same-sex marriage, on moral grounds, those very grounds are illicit under the proper theory of (say) the Equal Protection Clause. Perhaps the public is split along lines that suggest, or do not suggest, some kind of bias. If members of identifiable groups - religious or otherwise-are not likely to be outraged, Condorcet might believe that the existence of outrage among other such groups does not have much epistemic value. With respect to cascade effects, Condorcet must inquire into the social and political dynamics by which the public thinks as it does.

Perhaps Condorcet would like to consult the wisdom of the crowd to obtain an answer to the meta-question whether there is a bias or cascade, but on the meta-question, a bias and a cascade may also be at work (and so too on the meta-meta-question). Perhaps Condorcet can work with presumptions of one or another kind. If he is particularly humble, he will find a bias or suspect a cascade only if he is very firmly convinced that one or the other is present.

The epistemic argument for considering public outrage emerges as plausible but quite fragile. For the argument to have any force at all, public outrage must reflect a consensus on some proposition of fact or value that bears on the legal conclusion. Even if it does so, such outrage may be a product of a systematic bias or some kind of cascade. Judges lack good tools for investigating that question. If there is a consensus within the a relevant community on a question of law, or on a question that bears on the right answer to a question of law, then judges might pay attention to that consensus. But in hard cases, these circumstances will be rare. 


\section{E. Beyond Outrage (Again)}

To the extent that the epistemic point is taken seriously, we might well wonder about the focus solely on outrage. ${ }^{105}$ Perhaps outrage is simply an extreme point along a continuum of disapproval, starting with mild disagreement and culminating in outrage. Under the CJT, what matters is numerosity, not intensity. Suppose that 90 percent of the public believes that the Court would be wrong to strike down bans on polygamous marriages, or to rule that the President lacks the authority to commit troops to combat an apparent threat. At first glance, outrage is not important. What matters is whether the underlying judgment is widely held.

As I have noted, the Court's decision to invalidate a ban on same-sex sodomy seemed to have a great deal to do with a belief that invalidation fit with emerging social values. ${ }^{106}$ Thus the Court said that "In the United States criticism of Bowers has been substantial and continuing, disapproving of its reasoning in all respects," ${ }^{107}$ and the Court emphasized "an emerging awareness that liberty gives substantial protection to adult persons in deciding how to conduct their private lives . ..." would disagree with a decision, that point might seem relevant too, even if their disagreement is much milder than outrage. Armed with an understanding of some of the arguments thus far, we can better appreciate two time-honored views about the appropriate role of the judiciary in American government.

1. Thayerism. Begin with the view associated with James Bradley Thayer, which asks judges to defer to any plausible understanding of the Constitution. ${ }^{109}$ Thayer argued that because the American Constitution is often ambiguous, those who decide on its meaning must inevitably exercise discretion. ${ }^{110}$ Thayer's argument, in brief, was that courts should strike down laws only "when those who have the right to make laws have not merely made a mistake, but have made a very clear one,- - so clear that it is not open

\footnotetext{
${ }^{105}$ Cf. Posner \& Sunstein, supra note.

${ }^{106}$ See Lawrence v. Texas, 539 U.S. 558, 572, 576 (2003).

${ }^{107} I d$. at 576.

${ }^{108} I d$. at 572.

${ }^{109}$ See Thayer, supra note 14; Vermeule, supra note.

${ }^{110}$ See Thayer, supra note 14, at 144 (noting that laws "will seem unconstitutional to one man, or body of men, may reasonably not seem so to another; ... the constitution often admits of different interpretations; . .. there is often a range of choice and judgment ... ").
} 
to rational question."111 The question for courts "is not one of the mere and simple preponderance of reasons for or against, but of what is very plain and clear, clear beyond a reasonable doubt....."112

Thayer was concerned about public judgments in general, not about outrage in particular. There is an unmistakable Condorcetian dimension to Thayer's own argument for the view that courts should uphold government decisions unless they are unconstitutional "beyond a reasonable doubt." ${ }^{, 113}$ If the public and its representatives, who have their own duty of fidelity to the document, have understood a constitutional provision in a certain way, then the Court should pay respectful attention to their views. At the very least, a point of this kind provides a plausible reason for the Court to take account of the constitutional views of other branches of the national government, ${ }^{114}$ and perhaps of the constitutional judgments of the high courts of other nations. ${ }^{115}$ If other branches have focused squarely on the constitutional question, and reached a consensus in favor of one or another view, the Court might well pay attention for epistemic reasons.

2. Social commitments and the place of consensus. On an alternative view, the Court should pay close attention to existing social commitments in deciding when and whether to strike down legislation. Indeed, some of the most aggressive invalidations by the Court have been defended on the ground that they reflect widespread social judgments. ${ }^{116}$ In some cases, the Court has explicitly referred to such judgments as a basis for invalidating legislation. At first glance, it is puzzling to suggest that the Supreme Court should strike statutes down on this ground. ${ }^{117}$ But some statutes, especially at the state level, may reflect judgments of fact or morality that are inconsistent with the views of the public at large. If this is so, and if the Court can reliably measure

\footnotetext{
${ }^{111} \mathrm{Id}$

${ }^{112} I d$. at 151.

${ }^{113} \mathrm{Id}$.

${ }^{114}$ See, e.g., Rostker v. Goldberg, 453 U.S. 57, 64 (1981) (holding that when Congress has specifically considered the question of an act's constitutionality the "customary deference accorded the judgments of Congress are certainly appropriate”).

${ }^{115}$ See Posner \& Sunstein, supra note.

${ }^{116}$ See, e.g., Richard A. Posner, Sex and Reason (1994) (defending Griswold on such grounds); Michael Klarman, From Civil Rights to Jim Crow (2006) (defending Brown on such grounds); Harry Wellington, Common Law Rules and Constitutional Double Standards: Some Notes on Adjudication, 83 YALE L.J. 221 (1973) (defending Roe on such grounds).

${ }^{117}$ See JoHn HART ELY, DEMOCRACY AND DISTRUST (1983).
} 
public convictions, there is a plausible Condorcetian justification for taking them into account, at least on a certain view of constitutional interpretation.

Interesting debates might be imagined between Thayerians, reluctant to invalidate legislation on epistemic grounds, and those who are willing to do so on those same grounds. Thayerians would be tempted to emphasize the lack of good tools by which judges might measure public convictions; their adversaries would respond that it makes no sense to identify any particular statute, especially at the state level, with the will of the public. What is of interest here is that both sides are likely to raise a simple question: What makes outrage distinctive, if the epistemic argument is the governing one?

If an answer exists, it is that outrage suggests a degree of both confidence and intensity, in a way that strengthens the epistemic credentials of the public judgment. Recall that under the CJT, a successful answer from a large group can be expected if most people are at least more that 50 percent likely to be right. The key point is that if most people are confident that they are right, we might be able to find that the conditions for a correct group answer are more likely to be present. When people are less confident of a position, their views tend to moderate $;{ }^{118}$ and it is hard to be outraged without a degree of confidence. Moreover, confidence is associated with accuracy. ${ }^{119}$ Of course confident people are often wrong. But confidence has been found to be "associated with correctness for both individual and group performance." ${ }^{120}$ We might therefore think that when the public is outraged, it is more likely to be confident and hence its members are more likely to be right.

These points must be taken with many grains of salt. People might be confident about some highly technical issue of law, but they might not be outraged if judges give the wrong answer, simply because the issue is highly technical and little might turn on its resolution. Alternatively, people might be outraged even though they are not entirely confident, simply because the stakes are so high. Perhaps outrage, when it is exists, is

\footnotetext{
118 See Robert S. Baron et al., Social Corroboration and Opinion Extremity, 32 J. EXPERIMENTAL SoC. PSYCHOL. 537, 538 (1996).

${ }^{119}$ See Reid Hastie, ReVIEW Essay: Experimental Evidence of Group ACCuRAcy, in INFormation PoOLING AND GROUP Decision MAKING 129, 133-46 (Bernard Grofman \& Guillermo Owen eds., 1983).

120 See id. at 148.
} 
associated with systematic bias or with cascade effect. Hence outrage is an imperfect proxy for confidence, just as confidence is an imperfect proxy for accuracy. ${ }^{121}$

\section{Outrage and Validations (with Notes on Statutory Interpretation)}

\section{A. The Problem}

The public might be outraged by validations as well as by invalidations. Indeed, the public reaction to Supreme Court decisions seems to depend on the merits, not on whether the Supreme Court has upheld or struck down the decisions of the elected branches. If the Court ruled, tomorrow, that racial segregation by state governments is constitutionally unobjectionable, an intense reaction would be entirely predictable. If the Court said, next week, that the Bill of Rights does not apply to the states, the public would indeed be outraged. Let us imagine, then, a Justice Thayer, who accepts the following propositions:

2A. The President's national wiretapping program does not violate the Constitution.

2B. The Establishment Clause does not apply to the states; it follows that mandatory school prayer does not violate the Clause.

2C. The Takings Clause allows the government to characterize any minimally plausible justification as a "public use," so as to allow it to take private property so long as compensation is paid. ${ }^{122}$

${ }^{121}$ The analysis thus far has broader implications. The tension between judicial review and democracy qualifies as such only on the basis of certain understandings of both judicial capacities and democracy itself. The tension is serious if we believe that democratic self-government requires the public, and not the judges, to decide relevant moral questions. But why, exactly, might we think that? The consequentialist and epistemic arguments help to provide answers.

If Thayerism is understood through a Condorcetian lens, a deferential judicial role is best defended on the ground that the public is far more likely to be right than the federal judiciary. An evident problem with this position is that a systematic bias or a cascade might have led the public in the wrong direction; an additional problem is that the views of the public may not involve any proposition that bears on constitutional meaning. If Thayerism is understood in consequentialist terms, the argument would be that even if judges have special access to the document's meaning, the results will be better, at least on occasion, if they attend to the public's view. It is certainly open for a consequentialist to believe that selfgovernment is an intrinsic as well as instrumental good, and that any decision to thwart the democratic will creates a bad consequence by definition. My goal with these brief remarks is not to take sides in this large debate, but to specify some of the grounds on which democratic objections to judicial review might be both defended and challenged. 
Assume that the public would be outraged by any of these decisions. It should be immediately clear that cases $2 \mathrm{~A}-2 \mathrm{C}$ are importantly different from cases $1 \mathrm{~A}-1 \mathrm{~F}$, because the former involve validation of government decisions. How, if at all, should Justice Thayer take account of the prospect of public outrage? How, if at all, should his analysis differ from that of Justices Bentham and Condorcet in cases 1A-1F?

If these questions seem puzzling, we might note that outrage does play an explicit role in several areas of constitutional law, and here the Court has used outrage as a reason for invalidating legislation. In an early substantive due process case, the Court asked whether a disputed practice would "shock the conscience," in a way that would "offend those canons of decency and fairness which express the notions of justice of Englishspeaking peoples . . ..”123 In deciding whether a punishment is cruel and unusual, the Court refers to "evolving standards of decency," 124 an inquiry that is meant to attend to public judgments about what kinds of punishments are morally acceptable or instead beyond the bounds of "decency" (and in that sense outrageous). There seems to be an implicit Condorcetian dimension to these rulings, with the suggestion that widespread moral disapproval — and it is agreed that the disapproval needs to be widespread ${ }^{125}$ —is a measure of the moral acceptability of the practice. Insofar as the Court refers to evolving social values in due process adjudication, ${ }^{126}$ its decisions can also be taken in Condorcetian terms.

\section{B. Thayerians and Outrage}

Let us stipulate that Thayer is a consequentialist and that he is not committed to Kantian adjudication as a matter of abstract principle. Indeed, let us stipulate that Thayer is a Thayerian for consequentialist reasons. ${ }^{127}$ As a consequentialist, Thayer is certainly willing to pay attention to outrage, at least if it will have harmful effects. But cases 2A2C are different from cases $1 \mathrm{~A}-1 \mathrm{~F}$, because even if outrage is present, it has a simple

\footnotetext{
${ }^{122}$ Cf. Kelo v. City of New London, 545 U.S. 469 (2005).

${ }^{123}$ Rochin v. California, 342 U.S. 165, 169 (1952).

${ }^{124}$ The test originated in Trop v. Dulles, 356 U.S. 86, 101 (1958).

${ }^{125}$ See Roper v. Simmons, 543 U.S. 551, 564-68 (2005) (evaluating whether there was truly a "national consensus" against imposition of juvenile death penalty and finding it persuasive that a majority of states had rejected such a penalty).

${ }^{126}$ See Lawrence v. Texas, 538 U.S. 558, 572, 576 (2003).

${ }^{127}$ See Vermeule, supra note.
} 
outlet: The public can turn its outrage into legislation. If the public opposes the President's national wiretapping program, it can ban it. If the public wants to forbid school prayer, it can do so, certainly at the state level and potentially through national legislation as well; Thayer himself would be reluctant to invalidate national legislation to this effect. If state or national governments seek to impose fresh restrictions on takings of private property, it can do exactly that. For this reason, the consequentialist arguments for taking account of outrage are, at the very least, much weakened in the case of validations.

Now turn to the question of humility. Even if Thayer thinks that he might be wrong, the stakes are significantly lower than in cases $1 \mathrm{~A}-1 \mathrm{~F}$, again because there is a democratic corrective for Thayer's error. Indeed, Thayer's willingness to validate legislation, in cases 2A-2C and more generally, might itself be influenced by a kind of rough-and-ready Condorcetianism. If legislation has been enacted, the public probably favors it, at least much of the time, and public approval gives some reason to believe that the legislation is justified in terms of facts and values (supposing again a theory of interpretation for which public approval has epistemic value). Of course well-organized private groups might be responsible for legislation, and the public would not care or might even disapprove; but as a humble judge, Thayer might be unwilling to ask hard questions about that possibility.

And if Thayer puts the consequentialist and epistemic points together, he is not likely to be deterred, from his Thayerianism, by the prospect of public outrage at validations. The consequences of validations that produce outrage are not likely to be especially damaging, and because he is dealing with measures that have passed through democratic channels, the existence of outrage will usually lack much epistemic weight.

The question of statutory interpretation can be understood in similar terms. Perhaps people would be very upset if the Court ruled that the Endangered Species Act forbids some important project, or that the Civil Rights Act of 1964 bans affirmative action. But even if such rulings produce outrage, the public can respond with legislative change. For this reason, the consequentialist objection is greatly weakened. It is true that a judge might hesitate to interpret an ambiguous statute in a certain way if all or almost 
all members of the (relevant) community believe that his view is wrong. ${ }^{128}$ For Condorcetian reasons, it makes sense to pay attention to the views of relevant others. But public outrage may offer no relevant information at all. Suppose that the public wants to permit affirmative action, or to limit the reach of the Endangered Species Act. Its desires may well tell us exactly nothing about the proper interpretation of the relevant statutes.

Of course the prevailing theory of statutory interpretation is critical here. If questions of political morality matter to that theory, public outrage might matter. ${ }^{129}$ But if the judge's view is a product of the statutory text and structure, the views of the public, and its likely outrage, would seem uninformative. And to the extent that public outrage does offer some kind of signal that the Court may be wrong, there is less reason for concern, because the Court's error can be corrected. In any case, it is not clear that in the domain of statutory interpretation, public judgments provide any relevant information about whether the Court is correct.

\section{Complications}

These points are not necessarily decisive. It is often difficult to enact new legislation or to amend statutes, even when there is general agreement that such legislation or such an amendment is a good idea. In the constitutional domain, a consequentialist judge might be somewhat more inclined to strike down an enactment if validation would produce widespread outrage; and if the views of the public do have epistemic value, perhaps outrage at the prospect of validation could operate as a tiebreaker or more. The democratic objections to judicial invalidation seem weakened if the public would be greatly disturbed by validation. ${ }^{130}$ As we have seen, the Court does, in some areas of the law, consider widespread public outrage as a reason to invalidate legislation.

${ }^{128}$ Chevron, Inc. v. NRDC, 467 US 837 (1984), famously holds that courts must respect agency interpretations of ambiguous terms, so long as those interpretations are reasonable. Chevron can therefore be understood as a testimonial to judicial humility in the face of statutory ambiguity, not because of Condorcetian factors, but because of a belief in the superior accountability and technical specialization of the relevant agency. See id.

${ }^{129}$ See Ronald Dworkin, Law’s Empire (1985).

${ }^{130}$ Consider Griswold v. Connecticut, 381 US 479 (1965), in which the Court struck down a ban on the use of contraceptives by married people, a ban that was limited to one state and that was widely regarded as indefensible or even outrageous within the nation. In a federal system, it is entirely predictable that one state will sometimes engage in actions that other states will find outrageous. 
In the abstract, the idea of outrage at validations might seem puzzling, but it is certainly imaginable for one state, or a few states, to enact legislation of which the general public greatly disapproves. In invalidating such legislation, the Court might be vindicating widespread judgments against a small minority. Validation of legislation generally perceived to be outrageous might also trigger fears of widespread abridgements of important rights and interests; imagine a decision to validate some restriction on the right to use contraceptives. In most real-world cases, the public is likely to be divided, and a national consensus in opposition to the law that is being validated would be rare. ${ }^{131}$ But even if most of the public would be outraged by validation, it might not be so easy to produce a legislative corrective, at least not if a particular state is a genuine outlier or if a well-organized set of interests opposes that corrective.

In a very hard case of statutory interpretation, perhaps a consequentialist judge, or a humble one, should construe a statute so as to avoid public outrage; perhaps that is the right course when the judge is otherwise in or close to equipoise. ${ }^{132}$ But if judges cannot reliably decide whether outrage would be present, it is far more plausible to say that they should simply refuse to consider the question at all.

It follows that in the context of validations and statutory interpretation, there is a strong rule-consequentialist argument for refusing to consider public outrage in deciding what to do. If courts refuse to consider outrage, they need not undertake an inquiry that might be difficult. And as we have seen, judges may not have excellent or even decent tools for knowing whether outrage would be present, or what consequences would result from outrage, or what epistemic credentials outrage might have. It follows that Justice Thayer will be inclined not to take account of outrage and will vote his convictions, as expressed in $2 \mathrm{~A}-2 \mathrm{C}$.

\section{Originalism, Moral Readings, and Outraged Minorities}

I have suggested that the argument for considering outrage is sensitive to the prevailing theory of interpretation. If a judge accepts originalism or is committed to

\footnotetext{
131 But see Griswold, supra. Validation of the statute in Griswold, even in 1965, would have met widespread public disapproval.

${ }^{132} C f$. DWORKIN, supra note.
} 
moral readings of the Constitution, the analysis must be somewhat different. It must be similarly altered if outrage is felt by a minority rather than a majority.

\section{A. Originalism}

Assume that Justice Berger is an originalist; she believes that the meaning of the Constitution is settled by the original understanding of the ratifiers. She accepts the following propositions: ${ }^{133}$

3A. The Second Amendment forbids existing gun control legislation.

3B. Article II, section 1 forbids the creation of independent regulatory agencies, such as the National Labor Relations Board, the Federal Communications Commission, and the Federal Reserve Board.

3C. The Equal Protection Clause does not ban discrimination on the basis of sex.

Let us suppose too that under Berger's approach to constitutional interpretation, stare decisis is not controlling; when the Court's precedents are egregiously wrong, as she believes that it is in these cases, the Constitution should prevail, not the precedents. ${ }^{134}$ At the same time, Berger believes, in cases 3A-3C, that a ruling would produce a great deal of public outrage.

1. Originalism and consequences. Berger's reaction to the prospect of outrage might well depend on why, exactly, she is an originalist. Suppose that she is an originalist because of her judgment about what is entailed by the very idea of interpretation. ${ }^{135}$ She believes that attention to the original understanding is required if judges are to "interpret" the founding document rather than to make it up. If so, she is unlikely to care about intense public opposition. Judges are obliged to interpret the document, and the results do not matter.

But by virtue of her theory of interpretation, Justice Berger is not compelled to reason in this way. She might believe that originalism is entailed by the very idea of interpretation, but her theory of adjudication might be consequentialist, in the sense that she believes actions, including judicial actions, must be judged by reference to their

\footnotetext{
${ }^{133}$ I do not mean to suggest that these positions are, in fact, compelled by the original understanding.

${ }^{134}$ This is apparently Justice Thomas' view; Justice Scalia has said that Justice Thomas “doesn't believe in stare decisis, period. If a constitutional authority is wrong, [Thomas] would say, 'Let's get it right.' I wouldn't do that.” Quoted in Stephen Presser, Touting Thomas, LegAL AfF. (Jan./Feb. 2005).

${ }^{135}$ See Prakash, supra note.
} 
consequences. Justice Berger might therefore be interested in the possibility of exercising the "passive virtues." On this view, the appropriate steps, by judges who are originalists, are legitimately influenced by the consequences of those steps. Such an originalist would not be inclined to defy the original understanding in order to avoid bad consequences. But she might seek to avoid the key question on grounds of justiciability-certainly if the invocation of those grounds is defensible, or (preferably) right, on originalist grounds. In short, Justice Berger might have a nonconsequentialist theory of interpretation but also a consequentialist theory of adjudication, at least for purposes of deciding whether to exercise the passive virtues.

Consider a different type of originalist, one who considers originalism to be "the lesser evil, ${ }^{, 136}$ in the sense that it will produce better results than any other approach to interpretation. For such an originalist, the justification of originalism is itself consequentialist. On this view, originalism is likely to produce the best outcomes, all things considered. Consider the illuminating suggestion by Randy Barnett, a committed originalist: "Given a sufficiently good constitutional text, originalists maintain that better results will be reached overall if government officials-including judges-must stick to the original meaning rather than empowering them to trump that meaning with one that they prefer." ${ }^{, 137}$

Such an originalist might consider public opposition to be highly relevant. If Justice Berger is an originalist for consequentialist reasons, she is unlikely to favor originalism though the heavens may fall. The consequentialist considerations that justify originalism might lead this kind of originalist to try to avoid rulings of the sort indicated by 3A-3C, certainly if the consequences of such rulings would be very bad. Such an originalist would not interpret the Constitution in a way that violates the originalist understanding, but here too justiciability doctrines might be invoked to prevent the most radical rulings. Of course this result is not compelled. An originalist might believe that an insistence on originalism, producing 3A-3C, would produce good results, not bad ones, even if the public is outraged. The only point is that certain kinds of originalists would be entirely willing to take account of consequences and hence of outrage.

\footnotetext{
${ }^{136}$ See Antonin Scalia, Originalism: The Lesser Evil, 57 U. CIN. L. REv. 849 (1989).

${ }^{137}$ Randy Barnett \& Cass Sunstein, Debate Club, Constitution in Exile?, http://legalaffairs.org/webexclusive/debateclub_cie0505.msp.
} 
2. Originalism and epistemology. For originalists of any kind, humility and the CJT are much less likely to be important considerations. Why should an originalist care if most Americans believe that the Constitution allows gun control legislation or independent regulatory commissions, or forbids sex discrimination? The public consensus tells us little and probably nothing about the originalist understanding. Surely judges should pay attention if other originalists read the history in a way that is consistent with propositions 3A-3C. But public outrage, as such, is neither here nor there.

The only qualification arises if other branches of government have decided, on originalist assumptions, to reject propositions 3A-3C. Perhaps originalists should also be Condorcetians, not in the sense that they should care about the views of the general public, but in the sense that they ought to attend to the consensus of those who use their preferred method. Here too, of course, a systemic bias or a cascade effect may be at work. If members of other branches reject $3 \mathrm{~A}$ because of such a bias, or if their judgment on $3 \mathrm{C}$ is a result of a legal cascade, there is no reason to pay careful attention to their opinions.

\section{B. Moral Readings}

Suppose that propositions $1 \mathrm{~A}-1 \mathrm{~F}$ are supported by a "moral reading" of the Constitution, which asks judges to treat the founding document as establishing moral aspirations, which they should attempt to place in the best possible light, consistent with respect for the past. ${ }^{138}$ Much of constitutional law does seem to reflect some kind of moral reading, for judicial judgments about the best moral understanding of constitutional principles sometimes play a large role in the Court's conclusions. ${ }^{139}$ For judges who are committed to moral readings, should public outrage receive consideration? Let us consider how Justice Hercules, ${ }^{140}$ a moral reader of the Constitution, would approach the consequentialist and epistemic arguments.

At first glance, Justice Hercules is unlikely to be impressed by those arguments. The point of the moral reading is to say (for example) how liberty and equality are best conceived in light of our practices; often the moral reading will run in the face of the

\footnotetext{
${ }^{138}$ See Ronald Dworkin, Freedom's Law: The Moral Reading of the American Constitution (2000).

${ }^{139}$ See, e.g., Lawrence v. Texas, 539 U.S. 558 (2003); Brown v. Bd. of Educ., 387 U.S. 483 (1954).

${ }^{140}$ See DWORKIN, supra note.
} 
public will, and sometimes the moral reading will produce outrage (if only because the existing practice is outrageous). If Justice Hercules attends to public outrage, he will not give moral readings at all; consider $1 \mathrm{~A}-1 \mathrm{~F}$ in this light. There is a further problem. Those drawn to moral readings tend to be deontologists, not consequentialists. ${ }^{141}$ Insofar as attention to outrage is justified on consequentialist grounds, the justification would seem uninteresting to those who endorse moral readings.

But this conclusion may be premature; both consequential and epistemic reasons may be available. Justice Hercules should not welcome futile or self-defeating judicial rulings. As we have seen, deontologists do, and should, recognize the possibility of consequentialist overrides. It follows that if the consequences of outrage are bad enough, Justice Hercules should pay attention to it. It is certainly possible for judges to favor moral readings of the Constitution, and to see such readings in deontological terms, while also holding a consequential account of adjudication.

Insofar as public outrage is a signal of widely held moral convictions, it may well be worth attention for epistemic reasons, subject to the qualifications noted above. If the public's conception of liberty and equality is consistent with some practice, and if judicial validation of that practice might produce outrage, judges might pay attention to those facts.

\section{Outraged Minorities and Actual Practices}

The discussion thus far has assumed that the public as a whole would be outraged. This is a useful simplifying assumption, because it makes the consequentialist and epistemic issues more tractable. But most of the time, it is far more likely that public outrage will be limited to a minority and that most people will either approve of the Court's decision or at least not be outraged by it. When a minority is outraged, its reaction is not likely to be translated into law. How does all this bear on the normative question?

Begin with the Court's actual practices. There are few cases in which the Court's decision produced outrage within a strong majority of the public; the most obvious

${ }^{141}$ See DWORKIN, supra note; FLEMING, supra note. 
example is the Court's school prayer decision ${ }^{142}$ and, even there, no constitutional amendment has come close to ratification. Most of the Court's highly controversial decisions-involving school segregation, ${ }^{143}$ abortion, ${ }^{144}$ and property rights ${ }^{145}$-have spurred real outrage in segments of the public, not the nation as a whole. This fact suggests that either the Court is highly sensitive to the risks associated with widespread outrage, or more plausibly that political controls on the Court ensure that the justices rarely (seek to) produce outrageous results. Because of the appointments process, ${ }^{146}$ the justices are controlled, to some extent, by popular will; it is therefore most unlikely that they would be the kind of judges who would favor an interpretation of the Constitution that the public would regard as not only wrong but outrageously

How do the consequentialist and epistemic arguments fare in the context of views intensely held by a minority? The epistemic point is easier to handle. Justice Condorcet is not likely to be much moved by learning that a minority of the public strongly rejects his reading of the Constitution. If the majority agrees with him, or is indifferent, the diversity of views within the community deprive the judgments of the minority of much in the way of epistemic credentials. Of course matters would be different if the minority consisted of specialists whose views were entitled to particular respect. But minority opposition, even if intensely felt, will not greatly influence Condorcet.

The consequentialist arguments are less significantly affected. The question is whether outrage, localized as it may be, is likely to ensure futile or perverse outcomes, or overall bad consequences. If a minority is willing and able to resist a proposed remedy, the Court would do well to consider a remedy that will be more effective. If a minority is able to ensure that a result will be counterproductive, the analysis is not radically different from what it is if a majority is involved. The major difference is that if a majority approves of the Court's decision, or does not disapprove, the likelihood of bad consequences is reduced.

\footnotetext{
142 Abington Sch. Dist. v. Schempp, 374 U.S. 203 (1963).

143 See Brown v. Bd. of Educ., 347 U.S. 483 (1954).

${ }^{144}$ See Roe v. Wade, 410 U.S. 113 (1973).

145 See Kelo v. City of New London, 545 U.S. 469 (2005).

146 See LeE Epstein \& JefFrey Siegel, The Politics OF JUdicial Appointments (2006).
} 


\section{Nonjudicial Actors: Bentham and Condorcet in the Democratic Branches}

My emphasis throughout has been on the question whether judges should attend to public outrage. In this concluding section, I explore two related questions. The first is the relationship between popular constitutionalism and the arguments thus far; the second involves the implications of the argument for elected officials.

\section{A. We the People}

In recent years, many people have expressed interest in "popular constitutionalism" - in the view, with some roots in the founding period, that the meaning of the Constitution might be ultimately settled by We the People, not by the federal judiciary. ${ }^{147}$ On this view, the interpretations of the Supreme Court lack finality; the public is entitled to have the final say, not because it has ratified any constitutional amendment, but because it has settled on its own view about how the document is best understood. A related but more modest position emphasizes that other branches of government have an independent duty to be faithful to the Constitution, and that this independent duty calls for a degree of interpretive independence. ${ }^{148}$ On a prominent version of this view, for example, courts systematically "underenforce" the Constitution, because of their awareness of their own institutional limitations. ${ }^{149}$ It follows that the President and Congress might disapprove of (say) affirmative action or bans on same-sex marriage on constitutional grounds and take their own steps to prevent, and in a sense to invalidate, those same practices. It is not difficult to find examples of situations in which public officials, animated by their own views of constitutional commands, extend constitutional barriers in ways that the Supreme Court has refused to do. ${ }^{150}$

Perhaps public outrage can be seen as an especially dramatic exercise in popular constitutionalism, not least when it has concrete consequences. And when outrage is

\footnotetext{
${ }^{147}$ See KRAMER, supra note 4.

148 See FLEMING, supra note.

149 See Lawrence Sager, Fair Measure: The Legal Status of Underenforced Constitutional Norms, 91 HARV. L. REV. 1212 (1978).

${ }^{150}$ Observe, for example, President Reagan's executive orders on federalism and takings. Exec. Order No. 12,612, 3 C.F.R. 252 (1987) (requiring that executive agencies follow certain enumerated principles of federalism and consult states to the extent practicable before pursuing policies that would limit state “policymaking discretion”); Exec. Order No. 12,630, 53 Fed. Reg. 8859 (Mar. 15, 1988), reprinted in 5 U.S.C. § 601 (2000) (requiring executive agencies to conduct takings impact assessments when making regulatory decisions that may impact private property rights).
} 
expressed by the political branches, they may well be exercising their own independent interpretive authority, not least when they ask for more severe constitutional barriers than the Court has proved willing to erect. ${ }^{151}$ If we emphasize the epistemic argument for judicial attention to outrage, we might see that argument as embodying, even calling for, a kind of popular constitutionalism, or at least attention to the independent interpretive judgments of other branches.

I do not mean to speak directly here to the controversies over popular constitutionalism and the distribution of interpretive authority among the branches of government. Let us simply notice that when there is popular "backlash," a great deal depends on its grounds, at least if the goal is to assess the question whether it can be seen as an exercise in popular constitutionalism. Perhaps the public's judgment is not in any sense rooted in a judgment about constitutional meaning. Perhaps its outrage is a reflection of some kind of policy-driven, constitution-blind opprobrium. If a cascade is at work, the epistemic argument loses much of its force; so too if there is a systemic bias. On the other hand, "backlash" might legitimately be seen as constitutionally relevant insofar as it reflects a widespread and considered judgment about the merits of the constitutional issue. Here, as elsewhere, that question cannot be resolved without an account of constitutional interpretation and some information about what, exactly, lies beneath public outrage.

\section{B. Elected Officials}

Public outrage is relevant to the decisions of many public officials, including presidents, legislators, governors, and mayors. If they anticipate outrage in reaction to their decisions, they will often be deterred, even if they think that the outrage is unjustified or worse. Of course there is a large debate about whether representatives should make independent judgments or instead follow the views of those whom they represent. ${ }^{152}$ Return in this light to cases 1A-1D; suppose now that the President of the United States holds the relevant views as a matter either of constitutional interpretation or of fundamental principle. He might hesitate to press those views for either of the two

\footnotetext{
${ }^{151}$ For a recent example, see Kelo and the public reaction thereto.

${ }^{152}$ See Hannah PitKin, The ConcePt OF RePRESENTATION (1965).
} 
now-familiar reasons. He might believe that if he acts in accordance with his convictions, he will produce bad consequences. Alternatively, he might believe that his own commitments are unreliable, simply because so many people disagree.

Suppose, for example, that an American president concludes that same-sex marriages should be permitted; he believes that there is no good reason to ban such marriages, and indeed he believes that existing bans are a reflection of unjustified prejudice and hostility. He might nonetheless hesitate before insisting on this view. He might fear that such an insistence would compromise the ultimate goal of producing same-sex marriage. Perhaps an evolutionary process, involving a high degree of social learning, is the best way of achieving his preferred end. Perhaps his own approval would have a helpful influence on that process, but perhaps it would compromise his other important goals, including those relating to national security, energy independence, and income tax reform. Whether or not a court should be concerned about its limited political "capital," a national leader certainly has to decide when to spend that capital. If a president has an assortment of projects, he might well hesitate before pressing a commitment that will generate public outrage.

Consider here Abraham Lincoln's practices with respect to slavery. Lincoln always insisted that slavery was wrong. ${ }^{153}$ On the basic principle, Lincoln allowed no compromises. No justification was available for chattel slavery. But the fact that slavery was wrong did not mean that it had to be eliminated immediately, or that blacks and whites had to be placed on a plane of legal equality. In Lincoln's view, the feeling of "the great mass of white people” would not permit this result. ${ }^{154}$ In his most striking formulation, he declared: "Whether this feeling accords with justice and sound judgment, is not the sole question, if indeed, it is any part of it. A universal feeling, whether well or ill-founded, can not be safely disregarded."

Evidently Lincoln believed that efforts to create immediate social change in this especially sensitive area could have unintended consequences or backfire, even if those efforts were founded on entirely sound principle. It was necessary first to educate people

\footnotetext{
${ }_{153}^{15}$ BiCKel, supra note 2, at 64-68; HARRY V. JAFFA, CRISIS OF A House Divided (1959).

${ }^{154}$ Bickel, supra note 2, at 66 (quoting Abraham Lincoln, speech at Peoria, Illinois (Oct. 16, 1854)), in 2 THE COllected Works of ABRAHAM Lincoln 256 (Roy P. Basler ed., 1953).

${ }^{155} I d$.
} 
about the reasons for the change. Passions had to be cooled. Important interests had to be accommodated or persuaded to join the cause. Issues of timing were crucial. For Lincoln, rigidity about the principle was combined with caution about introducing the means by which the just outcome would be achieved. As Bickel emphasized, the point is highly relevant to constitutional law, especially in the area of social reform. ${ }^{82}$ It is easy to imagine why many elected officials might think in the same general terms suggested by Lincoln.

Alternatively, the President might think that if most people do see a good reason to some social practice, their views are entitled to respect. Indeed, an elected official may well have stronger epistemic reasons to consider the views of the public and the prospect of outrage than do judges, simply because the views of the public are far more likely to bear on the question that concerns the official. Suppose that an official believes that affirmative action should be abolished tomorrow, or that abortion should be banned, but that a strong majority of the public disagrees. The official might conclude that the public has relevant information on questions of both fact and value, and that she should hesitate before acting in a way that violates public convictions.

Here as well, however, the risk of systemic bias and cascade effects introduce important cautionary notes for politicians as well as for judges. A conscientious leader will inquire into the relevant risks in deciding whether to attend to the risk of outrage. The most general point is that an understanding of the consequentialist and epistemic arguments helps to explain debates over the concept of representation ${ }^{156}$ : Should politicians attempt to implement the public will, or should they understand themselves as having considerable discretion to depart from it ${ }^{157}$ ? Those who are skeptical about official discretion might have an epistemic point in mind. Perhaps the public is likely, on some questions, to know a great deal more than the relevant officials. Alternatively, they might believe, with Lincoln, that in certain domains, the consequences would be very bad if officials diverged too sharply from the public will. An appreciation of the epistemic and

\footnotetext{
156 See HANnA PitKin, THE CONCEPT Of REPRESENTATION (1965).

${ }^{157}$ The latter view is implicit in The Federalist No. 10, with its reference to "refin[ing] and enlarg[ing]" the public view. The Federalist No. 10, at 46 (James Madison) (George W. Carey \& James McClellan eds., 2001).
} 
consequential arguments should help to show when, and why, the diverging models of representation have particular force.

\section{Juries}

Should juries attend to the risk of public outrage? We can imagine a variety of possible cases. (a) A conviction of a defendant would produce significant outrage. (b) An acquittal of a defendant would produce significant outrage. (c) A civil verdict, imposing damages on a police department, would produce significant outrage. (d) A civil verdict, refusing to impose damages on a police department or a corporate polluter, would produce significant outrage. Does the analysis of juries differ from the analysis of courts?

In one respect, the analysis is indeed different: The epistemic argument for considering outrage seems weaker still. By its very nature, the jury will have heard the relevant facts, and it will therefore have a significant comparative advantage over the less informed public. It is hard to argue that on epistemic grounds, the jury should attend to a widespread public judgment in favor of conviction or liability. In addition, the jury is supposed to be representative of the public; and if it is indeed representative, it should be taken as a more knowledgeable microcosm. To be sure, the jury might bring its own moral convictions to bear on the resolution of some factual questions, and perhaps a widely held moral conviction on the part of the public as a whole, signaled by the presence of outrage, has some epistemic value. But it is hard to see circumstances in which jurors would do well, on epistemic grounds, to consult the views of a public that has (by hypothesis) failed to reflect on the facts and details of the case. ${ }^{158}$

In principle, the consequentialist argument is not so easily dismissed. Suppose that a criminal conviction would produce very bad consequences, such as riots that would ensure multiple deaths; suppose that a failure to convict would produce the same result. Suppose too that the jurors have an accurate crystal ball, so that they know, for certain, about those very bad consequences. At first glance, such consequences, if sufficiently bad, might well justify a refusal to convict. The issue is harder for criminal convictions;

${ }^{158}$ Compare the discussion of the deliberative opinion poll in JAMES FISHKIN, THE VOICE OF THE PeOPLE (1999); Fishkin convincingly contends that the results of a deliberative poll, conducted among informed citizens, are far more worthwhile than the results of a mere opinion poll, conducted by asking people simply to state their views on questions on which they have not reflected. A jury has an analogous advantage over the public generally. 
the deontological objection to conviction of the innocent, in order to protect other interests, is not easily rejected. ${ }^{159}$ Perhaps that objection can be overridden if the heavens would fall, or even if the consequences would be genuinely grave.

The simplest response would be based on several points. Jurors lack crystal balls; consequence-blind jury determinations are rarely likely to produce especially bad consequences; jury judgments might well be distorted by considering consequences. It is reasonable to think that for rule-consequentialist and systemic reasons, consequences are properly placed off-limits to the decisions of juries. We can imagine a possible world, and a possible case, in which this argument might be wrong. But in our world, and in our cases, it is almost certainly correct.

\section{Conclusion}

If judges are consequentialists and have perfect confidence in their forecasts, they might well be willing to consider the likely effects of public outrage as part of their assessment of the consequences of one or another course of action. On epistemic grounds, judges might conclude that a widely and deeply held set of public convictions deserves respectful attention, at least if judgments of fact or political morality are pertinent to the constitutional question. The epistemic justification does not apply if a systematic bias is likely to affect public judgments or if most people are participating in some kind of informational, moral, or legal cascade.

The strongest arguments against judicial attention to the effects of outrage are rule-consequentialist or based on considerations of system design. Perhaps the consequences will be best if judges put the effects of outrage entirely to one side. The broader point is that any judgment in favor of Kantian adjudication, or for restricting the set of considerations that judges may consider, must ultimately be defended in consequentialist terms. If people in certain social roles, such as the role of federal judges, blind themselves to certain considerations, the reasons are themselves consequentialist.

The arguments for considering the effects of outrage have the greatest force when judges are deciding whether to invalidate legislation. In the case of validations, there is far less reason to attend to public outrage. If the public greatly objects, it can respond by

${ }^{159}$ See, e.g., Steiker, supra note. 
changing the law through democratic means. To be sure, democratic change may be difficult. If courts had perfect tools by which to answer the underlying questions, some theories of interpretation would suggest that the risk of outrage is a reason to invalidate statutes, at least if judges are otherwise in equipoise. We have seen that widespread public outrage plays an occasional role in assessing whether punishment is cruel and unusual and whether certain statutes offend the Due Process Clause. But in the domain of validations, at least, there are usually good rule-consequentialist reasons to disregard outrage altogether. Those reasons are plausible but weaker in the case of invalidations.

I have emphasized that the strength of the argument for attending to outrage might well depend on the governing theory of interpretation. Originalists are not likely to accept the epistemic argument for considering outrage. For those who adopt a moral reading of the Constitution and who reject consequentialism, attending to outrage might seem jarring. Principle is what matters, and the fact that the public would be outraged does not seem to bear on what matters. But this conclusion is too quick, at least in some imaginable cases. Most deontologists believe in consequentialist overrides, and there is no reason to think that judicial judgments about the requirements of morality are unerring. For broadly similar reasons, originalists might themselves pay attention to public outrage on consequentialist grounds, even though the epistemic rationale seems weak.

These points bear on the much-discussed question whether public representatives should follow their own independent judgments or instead pay close attention to what the public believes and wants. Even if a representative's beliefs diverge from that of the public, she might hesitate to insist on those judgments if her insistence would disserve her most important projects, or if she believes that the views of the public provide a signal that her own views are wrong. But my focus has been on the behavior of courts. In the general run of cases, outrage is indeed irrelevant; the rule-consequentialist objection is convincing. In imaginable circumstances, however, judges legitimately consider public outrage because and to the extent that consequences matter, and because and to the extent that outrage provides information about the proper interpretation of the Constitution. 
Readers with comments should address them to:

Professor Cass R. Sunstein

University of Chicago Law School

1111 East 60th Street

Chicago, IL 60637

csunstei@midway.uchicago.edu 


\section{Chicago Working Papers in Law and Economics (Second Series)}

For a listing of papers 1-200 please go to Working Papers at http://www.law.uchicago.edu/Lawecon/index.html

201. Douglas G. Baird and Robert K. Rasmussen, Chapter 11 at Twilight (October 2003)

202. David A. Weisbach, Corporate Tax Avoidance (January 2004)

203. David A. Weisbach, The (Non)Taxation of Risk (January 2004)

204. Richard A. Epstein, Liberty versus Property? Cracks in the Foundations of Copyright Law (April 2004)

205. Lior Jacob Strahilevitz, The Right to Destroy (January 2004)

206. Eric A. Posner and John C. Yoo, A Theory of International Adjudication (February 2004)

207. Cass R. Sunstein, Are Poor People Worth Less Than Rich People? Disaggregating the Value of Statistical Lives (February 2004)

208. Richard A. Epstein, Disparities and Discrimination in Health Care Coverage; A Critique of the Institute of Medicine Study (March 2004)

209. Richard A. Epstein and Bruce N. Kuhlik, Navigating the Anticommons for Pharmaceutical Patents: Steady the Course on Hatch-Waxman (March 2004)

210. Richard A. Esptein, The Optimal Complexity of Legal Rules (April 2004)

211. $\quad$ Eric A. Posner and Alan O. Sykes, Optimal War and Jus Ad Bellum (April 2004)

212. Alan O. Sykes, The Persistent Puzzles of Safeguards: Lessons from the Steel Dispute (May 2004)

213. Luis Garicano and Thomas N. Hubbard, Specialization, Firms, and Markets: The Division of Labor within and between Law Firms (April 2004)

214. Luis Garicano and Thomas N. Hubbard, Hierarchies, Specialization, and the Utilization of Knowledge: Theory and Evidence from the Legal Services Industry (April 2004)

215. James C. Spindler, Conflict or Credibility: Analyst Conflicts of Interest and the Market for Underwriting Business (July 2004)

216. Alan O. Sykes, The Economics of Public International Law (July 2004)

217. Douglas Lichtman and Eric Posner, Holding Internet Service Providers Accountable (July 2004)

218. Shlomo Benartzi, Richard H. Thaler, Stephen P. Utkus, and Cass R. Sunstein, Company Stock, Market Rationality, and Legal Reform (July 2004)

219. Cass R. Sunstein, Group Judgments: Deliberation, Statistical Means, and Information Markets (August 2004, revised October 2004)

220. Cass R. Sunstein, Precautions against What? The Availability Heuristic and Cross-Cultural Risk Perceptions (August 2004)

221. M. Todd Henderson and James C. Spindler, Corporate Heroin: A Defense of Perks (August 2004)

222. $\quad$ Eric A. Posner and Cass R. Sunstein, Dollars and Death (August 2004)

223. Randal C. Picker, Cyber Security: Of Heterogeneity and Autarky (August 2004)

224. Randal C. Picker, Unbundling Scope-of-Permission Goods: When Should We Invest in Reducing Entry Barriers? (September 2004)

225. Christine Jolls and Cass R. Sunstein, Debiasing through Law (September 2004)

226. Richard A. Posner, An Economic Analysis of the Use of Citations in the Law (2000)

227. Cass R. Sunstein, Cost-Benefit Analysis and the Environment (October 2004)

228. Kenneth W. Dam, Cordell Hull, the Reciprocal Trade Agreement Act, and the WTO (October 2004)

229. Richard A. Posner, The Law and Economics of Contract Interpretation (November 2004)

230. Lior Jacob Strahilevitz, A Social Networks Theory of Privacy (December 2004)

231. $\quad$ Cass R. Sunstein, Minimalism at War (December 2004)

232. Douglas Lichtman, How the Law Responds to Self-Help (December 2004)

233. Eric A. Posner, The Decline of the International Court of Justice (December 2004)

234. Eric A. Posner, Is the International Court of Justice Biased? (December 2004)

235. Alan O. Sykes, Public vs. Private Enforcement of International Economic Law: Of Standing and Remedy (February 2005)

236. Douglas G. Baird and Edward R. Morrison, Serial Entrepreneurs and Small Business Bankruptcies (March 2005)

237. $\quad$ Eric A. Posner, There Are No Penalty Default Rules in Contract Law (March 2005)

238. Randal C. Picker, Copyright and the DMCA: Market Locks and Technological Contracts (March 2005)

239. Cass R. Sunstein and Adrian Vermeule, Is Capital Punishment Morally Required? The Relevance of Life-Life Tradeoffs (March 2005)

240. Alan O. Sykes, Trade Remedy Laws (March 2005)

241. Randal C. Picker, Rewinding Sony: The Evolving Product, Phoning Home, and the Duty of Ongoing Design (March 2005)

242. Cass R. Sunstein, Irreversible and Catastrophic (April 2005)

243. James C. Spindler, IPO Liability and Entrepreneurial Response (May 2005) 
244. Douglas Lichtman, Substitutes for the Doctrine of Equivalents: A Response to Meurer and Nard (May 2005)

245. Cass R. Sunstein, A New Progressivism (May 2005)

246. Douglas G. Baird, Property, Natural Monopoly, and the Uneasy Legacy of INS v. AP (May 2005)

247. Douglas G. Baird and Robert K. Rasmussen, Private Debt and the Missing Lever of Corporate Governance (May 2005)

248. Cass R. Sunstein, Administrative Law Goes to War (May 2005)

249. Cass R. Sunstein, Chevron Step Zero (May 2005)

250. Lior Jacob Strahilevitz, Exclusionary Amenities in Residential Communities (July 2005)

251. Joseph Bankman and David A. Weisbach, The Superiority of an Ideal Consumption Tax over an Ideal Income Tax (July 2005)

252. Cass R. Sunstein and Arden Rowell, On Discounting Regulatory Benefits: Risk, Money, and Intergenerational Equity (July 2005)

253. Cass R. Sunstein, Boundedly Rational Borrowing: A Consumer’s Guide (July 2005)

254. Cass R. Sunstein, Ranking Law Schools: A Market Test? (July 2005)

255. David A. Weisbach, Paretian Intergenerational Discounting (August 2005)

256. Eric A. Posner, International Law: A Welfarist Approach (September 2005)

257. Adrian Vermeule, Absolute Voting Rules (August 2005)

258. Eric Posner and Adrian Vermeule, Emergencies and Democratic Failure (August 2005)

259. Douglas G. Baird and Donald S. Bernstein, Absolute Priority, Valuation Uncertainty, and the Reorganization Bargain (September 2005)

260. Adrian Vermeule, Reparations as Rough Justice (September 2005)

261. Arthur J. Jacobson and John P. McCormick, The Business of Business Is Democracy (September 2005)

262. Adrian Vermeule, Political Constraints on Supreme Court Reform (October 2005)

263. Cass R. Sunstein, The Availability Heuristic, Intuitive Cost-Benefit Analysis, and Climate Change (November 2005)

264. Lior Jacob Strahilevitz, Information Asymmetries and the Rights to Exclude (November 2005)

265. Cass R. Sunstein, Fast, Frugal, and (Sometimes) Wrong (November 2005)

266. Robert Cooter and Ariel Porat, Total Liability for Excessive Harm (November 2005)

267. Cass R. Sunstein, Justice Breyer’s Democratic Pragmatism (November 2005)

268. Cass R. Sunstein, Beyond Marbury: The Executive’s Power to Say What the Law Is (November 2005, revised January 2006)

269. Andrew V. Papachristos, Tracey L. Meares, and Jeffrey Fagan, Attention Felons: Evaluating Project Safe Neighborhoods in Chicago (November 2005)

270. Lucian A. Bebchuk and Richard A. Posner, One-Sided Contracts in Competitive Consumer Markets (December 2005)

271. Kenneth W. Dam, Institutions, History, and Economics Development (January 2006, revised October 2006)

272. Kenneth W. Dam, Land, Law and Economic Development (January 2006, revised October 2006)

273. Cass R. Sunstein, Burkean Minimalism (January 2006)

274. Cass R. Sunstein, Misfearing: A Reply (January 2006)

275. Kenneth W. Dam, China as a Test Case: Is the Rule of Law Essential for Economic Growth (January 2006, revised October 2006)

276. C Cass R. Sunstein, Problems with Minimalism (January 2006, revised August 2006)

277. Bernard E. Harcourt, Should We Aggregate Mental Hospitalization and Prison Population Rates in Empirical Research on the Relationship between Incarceration and Crime, Unemployment, Poverty, and Other Social Indicators? On the Continuity of Spatial Exclusion and Confinement in Twentieth Century United States (January 2006)

278. Elizabeth Garrett and Adrian Vermeule, Transparency in the Budget Process (January 2006)

279. Eric A. Posner and Alan O. Sykes, An Economic Analysis of State and Individual Responsibility under International Law (February 2006)

280. Kenneth W. Dam, Equity Markets, The Corporation and Economic Development (February 2006, revised October 2006)

281. Kenneth W. Dam, Credit Markets, Creditors’ Rights and Economic Development (February 2006)

282. Douglas G. Lichtman, Defusing DRM (February 2006)

283. Jeff Leslie and Cass R. Sunstein, Animal Rights without Controversy (March 2006)

284. Adrian Vermeule, The Delegation Lottery (March 2006)

285. Shahar J. Dilbary, Famous Trademarks and the Rational Basis for Protecting “Irrational Beliefs” (March 2006)

286. Adrian Vermeule, Self-Defeating Proposals: Ackerman on Emergency Powers (March 2006)

287. Kenneth W. Dam, The Judiciary and Economic Development (March 2006, revised October 2006)

288. Bernard E. Harcourt: Muslim Profiles Post 9/11: Is Racial Profiling an Effective Counterterrorist Measure and Does It Violate the Right to Be Free from Discrimination? (March 2006)

289. Christine Jolls and Cass R. Sunstein, The Law of Implicit Bias (April 2006) 
290. Lior J. Strahilevitz, “How’s My Driving?” for Everyone (and Everything?) (April 2006)

291. Randal C. Picker, Mistrust-Based Digital Rights Management (April 2006)

292. Douglas Lichtman, Patent Holdouts and the Standard-Setting Process (May 2006)

293. Jacob E. Gersen and Adrian Vermeule, Chevron as a Voting Rule (June 2006)

294. Thomas J. Miles and Cass R. Sunstein, Do Judges Make Regulatory Policy? An Empirical Investigation of Chevron (June 2006)

295. Cass R. Sunstein, On the Divergent American Reactions to Terrorism and Climate Change (June 2006)

296. Jacob E. Gersen, Temporary Legislation (June 2006)

297. David A. Weisbach, Implementing Income and Consumption Taxes: An Essay in Honor of David Bradford (June 2006)

298. David Schkade, Cass R. Sunstein, and Reid Hastie, What Happened on Deliberation Day? (June 2006)

299. David A. Weisbach, Tax Expenditures, Principle Agent Problems, and Redundancy (June 2006)

300. $\quad$ Adam B. Cox, The Temporal Dimension of Voting Rights (July 2006)

301. Adam B. Cox, Designing Redistricting Institutions (July 2006)

302.

303.

Cass R. Sunstein, Montreal vs. Kyoto: A Tale of Two Protocols (August 2006)

Kenneth W. Dam, Legal Institutions, Legal Origins, and Governance (August 2006)

304.

305.

Anup Malani and Eric A. Posner, The Case for For-Profit Charities (September 2006)

Douglas Lichtman, Irreparable Benefits (September 2006)

306. M. Todd Henderson, Payiing CEOs in Bankruptcy: Executive Compensation when Agency Costs Are Low (September 2006)

307. Michael Abramowicz and M. Todd Henderson, Prediction Markets for Corporate Governance (September 2006)

308. Randal C. Picker, Who Should Regulate Entry into IPTV and Municipal Wireless? (September 2006)

309. Eric A. Posner and Adrian Vermeule, The Credible Executive (September 2006)

310. David Gilo and Ariel Porat, The Unconventional Uses of Transaction Costs (October 2006)

311. Randal C. Picker, Review of Hovenkamp, The Antitrust Enterprise: Principle and Execution (October 2006)

312. Dennis W. Carlton and Randal C. Picker, Antitrust and Regulation (October 2006)

313. Robert Cooter and Ariel Porat, Liability Externalities and Mandatory Choices: Should Doctors Pay Less? (November 2006)

314. Adam B. Cox and Eric A. Posner, The Second-Order Structure of Immigration Law (November 2006)

315. Lior J. Strahilevitz, Wealth without Markets? (November 2006)

316. Ariel Porat, Offsetting Risks (November 2006)

317. Bernard E. Harcourt and Jens Ludwig, Reefer Madness: Broken Windows Policing and Misdemeanor Marijuana Arrests in New York City, 1989-2000 (December 2006)

318. Bernard E. Harcourt, Embracing Chance: Post-Modern Meditations on Punishment (December 2006)

319. Cass R. Sunstein, Second-Order Perfectionism (December 2006)

320. William M. Landes and Richard A. Posner, The Economics of Presidential Pardons and Commutations (January 2007)

321. Cass R. Sunstein, Deliberating Groups versus Prediction Markets (or Hayek’s Challenge to Habermas) (January 2007)

322. Cass R. Sunstein, Completely Theorized Agreements in Constitutional Law (January 2007)

323. Albert H. Choi and Eric A. Posner, A Critique of the Odious Debt Doctrine (January 2007)

324. Wayne Hsiung and Cass R. Sunstein, Climate Change and Animals (January 2007)

325. Cass. R. Sunstein, Cost-Benefit Analysis without Analyzing Costs or Benefits: Reasonable Accommodation, Balancing and Stigmatic Harms (January 2007)

326. Cass R. Sunstein, Willingness to Pay versus Welfare (January 2007)

327. David A. Weisbach, The Irreducible Complexity of Firm-Level Income Taxes: Theory and Doctrine in the Corporate Tax (January 2007)

328. Randal C. Picker, Of Pirates and Puffy Shirts: A Comments on "The Piracy Paradox: Innovation and Intellectual Property in Fashion Design” (January 2007)

329. Eric A. Posner, Climate Change and International Human Rights Litigation: A Critical Appraisal (January 2007)

330. Randal C. Picker, Pulling a Rabbi Out of His Hat: The Bankruptcy Magic of Dick Posner (February 2007)

331. Bernard E. Harcourt, Judge Richard Posner on Civil Liberties: Pragmatic (Libertarian) Authoritarian (February 2007)

332. Cass R. Sunstein, If People Would Be Outraged by Their Rulings, Should Judges Care? (February 2007) 